Portland State University

PDXScholar

7-31-1992

\title{
1989 Chinese Pro-democracy Movement and U.S. News Media
}

Jie Sun

Portland State University

Follow this and additional works at: https://pdxscholar.library.pdx.edu/open_access_etds

Part of the Speech and Rhetorical Studies Commons

Let us know how access to this document benefits you.

\section{Recommended Citation}

Sun, Jie, "1989 Chinese Pro-democracy Movement and U.S. News Media" (1992). Dissertations and Theses. Paper 4583.

https://doi.org/10.15760/etd.6467

This Thesis is brought to you for free and open access. It has been accepted for inclusion in Dissertations and Theses by an authorized administrator of PDXScholar. Please contact us if we can make this document more accessible: pdxscholar@pdx.edu. 
AN ABSTRACT OF THE THESIS OF Jie Sun for the Master of Science in Speech Communication presented July 31, 1992 .

Title: 1989 Chinese Pro-democracy Movement and U.S. News Media

APPROVED BY THE MEMBERS OF THE THESIS COMMITTEE:

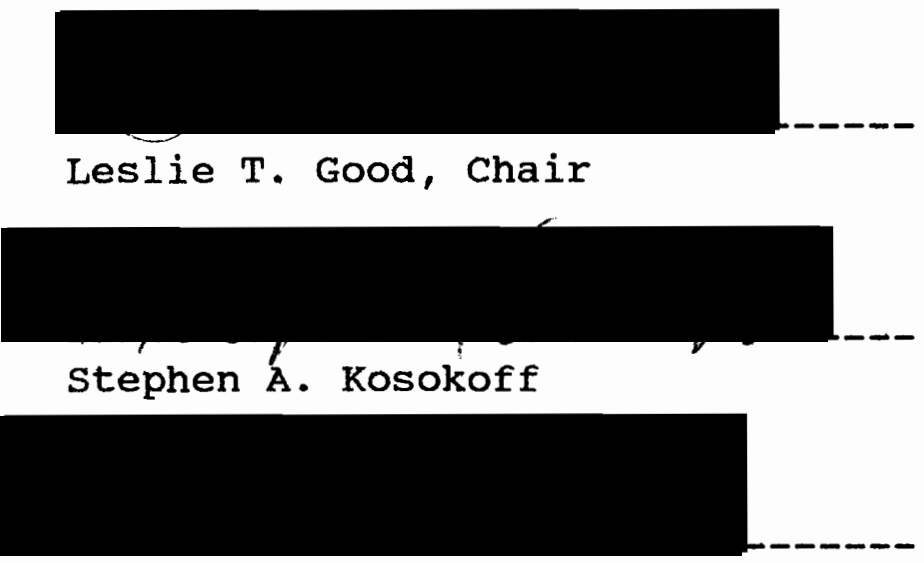

David Wrench

This thesis explores three aspects of the relationship between U.S. news media and the Chinese pro-democracy movement in 1989. These three aspects are: How much attention did U.S. newspapers give to the Chinese prodemocracy movement in 1989? How did U.S. newspapers portray the power struggle in the Chinese government during the time when the Chinese pro-democracy movement took place? Has there been any change in the image of China during and after the Chinese pro-democracy movement in 1989?

Research data are drawn from the following three U.S. 
newspapers: The New York Times, Washington Post, and Los Angeles Times.

Content analysis is adopted as the research method in this study. This research method is carried out in three parts targeting the three research questions mentioned above. The first part shows the total front-page space and number of news stories in the three U.S. newspapers. The front-page space and number of news stories in each newspaper is utilized to measure the degree of attention that each newspaper gave to the Chinese pro-democracy movement in 1989. The second part illustrates the power struggle in the Chinese government. Top Chinese officials are presented as either losing or gaining power based on the treatment they received from the three U.S. newspapers. The third part demonstrates the change in the image of China during and after the Chinese pro-democracy movement in 1989. Both positive and negative changes in the image of China are determined by the use of ideological and nonideological symbolic representations of China in news stories.

Research findings on the first research question show that both front-page space and number of news stories related to events in china increased dramatically in all three U.S. newspapers. Research findings on the power struggle in the chinese government showed that, in general, all three U.S. newspapers viewed the three top Chinese 
officials as losing power before military troops were used to control the situation in Beijing on June 4,1989 . Finally, research findings showed a negative change in the image of China during and the chinese pro-democracy movement, especially after the Chinese government regained control of Tiananmen Square by using military force on June 4, 1989. Implications for future research in mass communication are discussed and, finally, the thesis concludes with suggestions for further research in mass media and communication. 


\title{
1989 CHINESE PRO-DEMOCRACY MOVEMENT \\ AND U.S. NEWS MEDIA
}

BY

JIE SUN

A thesis submitted in partial fulfillment of the requirements for the degree of

\author{
MASTER OF SCIENCE \\ in \\ SPEECH COMMUNICATION
}

Portland State University

1992 
TO THE OFFICE OF GRADUATE STUDIES:

The members of the committee approve the thesis of Jie Sun presented July 31, 1992.

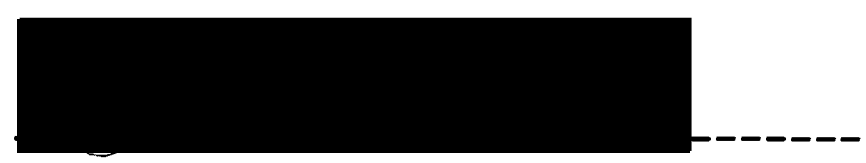

Leslie T. Good, Chair
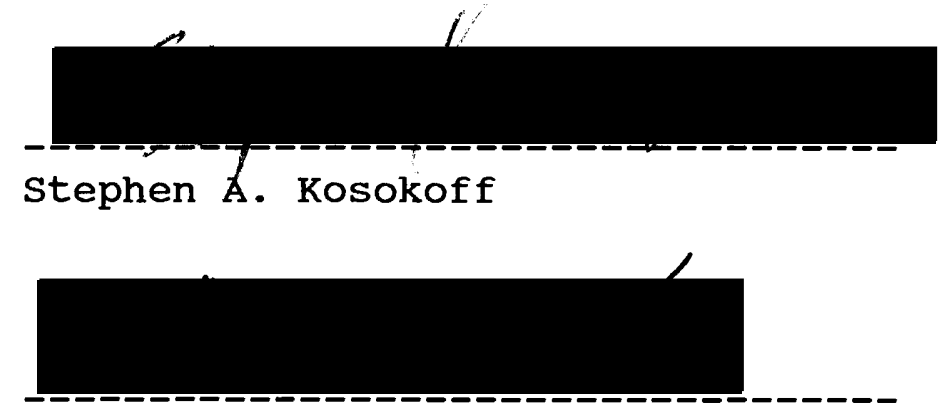

David Wrench

APPROVED :

Stephen Á. Kosokoff, Chair

Department of Speech Communication

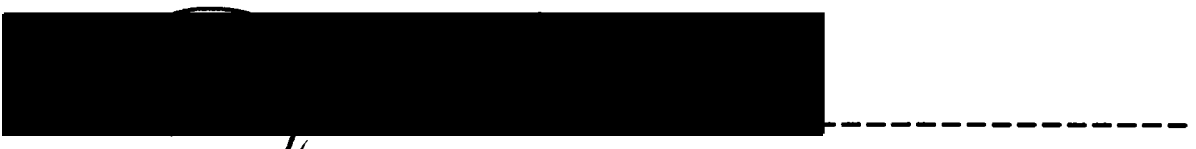

Roy W. Kctch, Vice Provost for Graduate Studies and research 


\section{DECICATED TO}

my great friends Stephen Kosokoff and

Terry Ann Rogers who made a turning

point in my life and my career 


\section{ACKNOWLEDGEMENTS}

The accomplishment of this thesis cannot be separated from the efforts of many people who shared their valuable time and experiences with me. My heart-felt gratitude goes to Steve Kosokoff, David Wrench and Devorah Lieberman for their guidance and encouragement.

It is with much appreciation and deep repect that I thank Leslie Good for her detailed instructions, guidance, and professional support in the entire process when I was working on my thesis.

I would also like to thank all of the friends and schoolmates who participated in the process of data collection which was time consuming and monotonous. Particularly, I want to thank Mei Liao for her consistent support, understanding, and patience. 
TABLE OF CONTENTS

PAGE

ACKNOWLEDGEMENTS $\ldots \ldots \ldots \ldots \ldots \ldots \ldots \ldots \ldots \ldots \ldots \ldots \ldots \ldots \ldots \ldots \ldots$

LIST OF TABLES $\ldots \ldots \ldots \ldots \ldots \ldots \ldots \ldots \ldots \ldots \ldots \ldots \ldots \ldots$

CHAPTER

I

INTRODUCTION $\ldots \ldots \ldots \ldots \ldots \ldots \ldots \ldots \ldots \ldots$

The Chinese Pro-democracy Movement

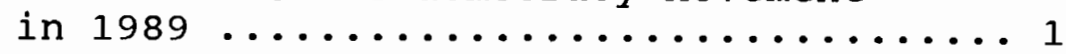

News Media and Political Movements .... 4

The U.S. News Media .............. 5

Issues in This Research ........... 7

structure of This Research .......... 9

II LITERATURE REVIEW ................. 11

Introduction $\ldots \ldots \ldots \ldots \ldots \ldots \ldots \ldots$

General Issues of News Media ........ 11

What is News?

Objective News Reporting

News Selection

Public Need for News

Theoretical Issues of Mass Media and

Mass Movement ............... 20

Basic Concepts in Mass

Communication Theory

Effects of Mass Media

Why Do Peoble Communicate?

Mass Media and Political

Movements

Specific Issues of Concern 


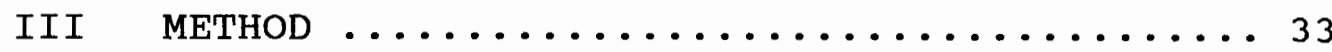

Introduction $\ldots \ldots \ldots \ldots \ldots \ldots . \ldots \ldots$

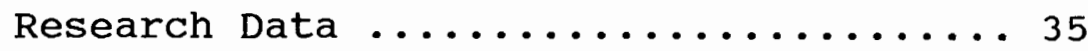

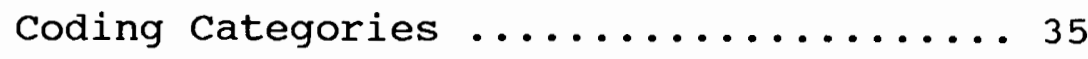

Procedure of Data Collection ......... 38

IV FINDINGS/ANALYSIS ................ 43

Chronology ....................43

Movement Coverage ...............44 46

Power struggle ................. 52

Change in the Image of China ........ 55

V CONCLUSION/IMPLICATIONS ............. 63

Introduction ...................63

Summary of Research Findings ........ 64

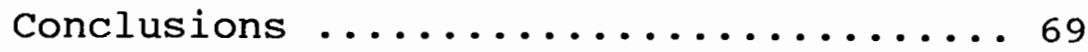

Limitations and Implications ........ 72

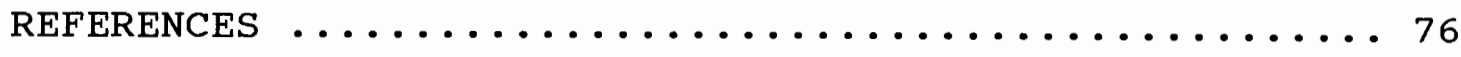

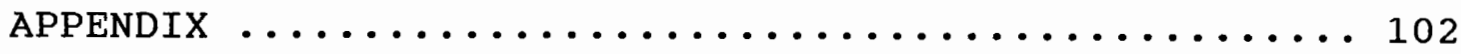




\section{LIST OF TABLES}

TABLE

PAGE

I Pre-movement $-2 / 5 / 89$ to $2 / 18 / 89 \ldots \ldots \ldots \ldots$

II Movement Coverage ................. 48

III Summary of Movement Coverage --

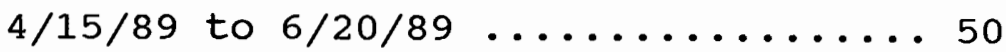

IV Post-movement -- $8 / 6 / 89$ to $8 / 19 / 89 \ldots \ldots \ldots \ldots 1$

V Power struggle - $5 / 5 / 89$ to $5 / 19 / 89 \ldots \ldots \ldots . \ldots 52$

VI Power struggle $-5 / 20 / 89$ to $6 / 4 / 89 \ldots \ldots \ldots 54$

VII Image of China $-2 / 5 / 89 /$ to $2 / 18 / 89 \ldots \ldots 6$

VIII Change in the Image of China ........... 57

IX Image of China -- $8 / 6 / 89$ to $8 / 19 / 89 \ldots \ldots \ldots 1$ 


\section{CHAPTER I}

\section{INTRODUCTION}

THE CHINESE PRO-DEMOCRACY MOVEMENT IN 1989

China embarked on the road of economic reform at the end of the 1970s. The experiment of economic reform brought about dramatic changes in every aspect of Chinese society. on the positive side, the increase in grain output from 1978 to 1984 was greater than the output realized in the preceding 20 years (1958-1977). Increases in personal incomes since 1978 have been greater than in the entire period from 1949 to 1977 . On the negative side, inflation and corruption in government agencies became rampant. Embezzlement and bribery were no longer unusual in people's daily lives.

Dissatisfaction in society turned into public outcry when the reformist leader Hu Yaobang died on April 15, 1989. The initial stage of the movement was demonstrations led by university students in Beijing who indirectly praised Hu Yaobang for his open tolerance of different opinions and criticized those who brought him down after the 1986-1987 student demonstrations in Beijing and Shanghai. Big posters were first posted in universities in Beijing and soon spread all over the capital. The demonstrators demanded a stop to 
corruption and reform of the political system and the economic system.

In early May, 1989, in observance of the May 4th Movement, students in a dozen cities responded to the call from the Beijing students and took to the street to express their dissatisfaction and demands. The movement rapidly spread over all the country.

The movement escalated after the demonstrators' attempt to have an equal and direct dialogue with the government failed. Three thousand hunger strikers began their sit-in protest in Tiananmen Square. The student movement won over sympathy and support from ordinary citizens all over the country. In a short period of time, from late April to midMay, 1989, people from all walks of life got involved in the movement.

Along with escalation of the demonstrations rose the demands of the demonstrators. The demands included resignation of top leaders of government and the communist party, release of all political prisoners, and freedom of the press. At this point, the demonstrations changed into a large-scale mass movement which was unprecedented since the Chinese communists took power in mainland China in 1949.

When international news media focused their attention on Gorbachev's visit to Beijing in May, 1989, they found that the first Sino-Soviet summit in 30 years was overshadowed by the pro-democracy movement. Tens of 
thousands of demonstrators occupied the center of the capital asking for more freedom and democracy. Gorbachev's welcoming ceremony had to be moved from Tiananmen Square to the airport. For chinese leaders, it was a great loss of face.

For more than six weeks the demonstrators occupied Beijing's Tiananmen Square, wnich is the symbol of the communist establishment in China. And for the first time in its 40-year rule, the communist party lost control of the capital.

$$
\begin{aligned}
& \text { The fact that there was a time in May } 1989 \\
& \text { when the government of China was overthrown as } \\
& \text { the real controlling authority will become } \\
& \text { part of China's history and is certain to } \\
& \text { affect China's future (Rosenthal, 1989). } \\
& \text { People from all walks of life took part in }
\end{aligned}
$$

demonstrations. Following students' independent

organizations, workers and journalists established their own independent unions. Fearing the possibility of unbearable consequences of the mass movement, the chinese government declared martial law in Beijing on May 20, 1989.

over one million people in the capital were galvanized by the declaration of martial law in Beijing. Beijing citizens took to the street and built roadblocks to prevent army troops from entering the city center. The army troops were either persuaded to leave or were pushed out of the city center more than once. On more than one occasion, the martial law seemed to be nullified by the people's power. 
The stalement lasted nearly two weeks until the Chinese government used military troops to regain control of the capital by force on June 4,1989 .

NEWS MEDIA and POLITICAL MOVEMENTS

According to Bond (1967), "It is the primary function of newspapers to communicate to the human race what its members do, feel, and think" (p.5). This function of news media is vital in modern societies. People in modern societies rely on news media to survive. As Bond (1967) stated:

Life has become so complex and its interests so manifold that even the specialists become baffled in their own fields of knowledge. The ordinary mortal caught in a maze of ecnonmics, science or invention needs to be led by the hand through its intricacies (p.6).

A similar point was further made clear by Gitlin when he said:

...people find themselves relying on the media for concepts, for images of their heroes, for guiding information, for emotional charges, for a recognition of public values, for symbols in general, even for language....mass media are, to say the least, a significant social force in the forming and delimiting of public assumptions, attitudes, and moods -- of ideology, in short (Gitlin, 1980, p.1-9).

In other words, news media have the power to influence people in formulating their opinions, making their decisions, and taking sides when they face disputing social issues.

Political movements, as one type of social activity, 
also depend on news media to send their messages to the public. Gitlin (1980) discussed the function of news media in political movements when he said that news media present any given political movement to the public regarding what the movement is and what purposes the movement intends to fulfill. To accomplish a certain goal, a political movement has to rely on large-scale communication means to reach and to mobilize the public.

The chinese pro-democracy movement in 1989 is an important social and political movement in contemporary Chinese history. It had tremendous impact on U.S.-China relations. How was the movement perceived by the American public? How was the movement presented to the American public by U.S. news media? Answers to these initial questions of interest became the driving force for the present study.

THE U.S. NEWS MEDIA

In Four Theories of The Press (Siebert, et al, 1976), one of the theoretical assumptions is,

...the press always takes on the form and coloration of the social and political

structures within which it operates.

Especially, it reflects the system of social control whereby the relations of individuals and institutions are adjusted (p.1).

The point is that there is no good or bad press from a theoretical perspective. The presses are just different from one another. However, the differences between 
different presses are not just cultural, historical, or political. Presses of industrialized and developed countries tend to be more influential than those of backward and less developed countries. Walker (1983) discussed the influence of different newspapers by saying that:

...one remnant of that world of 1945 still dominates much of the earth's intellectual, political and cultural life. The newspapers of the Grand Alliance have survived, and even expanded their influence (p.1).

After World War II, the United States became the leading democracy with its advanced material progress, technology, and military strength. Both U.S. domestic and foreign policies have strong effects on today's international relations. The U.S. newspapers, especially big ones like The New York Times and Washington Post, not only reflect the U.S. government's policies, but also have a great deal of influence on the setting of political agendas and the process of policy making.

Policymakers generally share the view that among the most significant impacts of the press occur early on the policymaking process, when it is not yet clear which issues will be addressed and what questions will be decided. Officials believe that the media do a lot to set the policy agenda and to influence how an issue is understood by policymakers, interest groups, and the public (Linsky, 1986, p.87).

Pierre Salinger (former President Kennedy's press secretary) once stated the importance of big newspapers in the United States. He said,

No top policy-maker in Washington starts his 
day without reading The New York Times... The Washington Post derives its importance from being read every morning by washington officialdom from the president on down (Walker, 1983, p.3).

The power and influence of the U.S. newspapers make it impossible to ignore the importance they carry in the case of any social and political movement, home and abroad. Therefore, it is meaningful to see how the U.S. newspapers portrayed the 1989 Chinese pro-democracy movement.

\section{ISSUES IN THIS RESEARCH}

The present research focuses on how some of the major U.S. newspapers represented the 1989 Chinese pro-democracy movement. Before the movement was suppressed by military troops on June 4, 1989, the Chinese pro-democracy movement captured the attention of international news media. News regarding the chinese pro-democracy movement got on the front pages of all major newspapers for several weeks. The Chinese pro-democracy movement in 1989 received a great deal of attention from the international news media. But exactly how much attention did U.S. newspapers give to the movement? Front-page space of newspapers is generally used as an important measurement to determine how much attention the newspapers give to a certain event.

Therefore, how much front-page space did some of the leading U.S. newspapers use to cover the events of the prodemocracy movement in China? Did some newspapers pay more 
attention to the movement than others did? Previous research provided some clues as to how and why front-page coverage could be used to measure the amount of attention that each newspaper gave to a given event (for a detailed discussion, see Chapter III).

Another issue is how some of the leading U.S. newspapers portrayed the power struggle at the top level of the Chinese government and the communist party. How accurate were the news reports in their prediction of the power struggle in the chinese government before the military troops put an end to the pro-democracy movement on June 4, $1989 ?$

This issue carries particular significance in this research in that the power struggle was not only part of the entire movement, but also a decisive factor that contributed to the final ending of the movement. In other words, the outcome of the political struggle played a key role in the way the chinese government handled the mass demonstrations in early June, 1989.

The last issue in this research is whether there has been any change in the image of China from the perspective of U.S. newspapers, during and right after the chinese prodemocracy movement in 1989.

The image of China changed dramatically after sino-U.S. normalization in 1979. Instead of symbolic representations like "Communist China" or "Red China," China has more often 
been referred to as "Mainland China" or simply "China" (Chang, 1989). This change in the image of China is considered positive because the symbolic representations after 1979 are non-hostile and non-ideological.

Has the pro-democracy movement affected the image of China from the perspective of the U.S. news media? If so, is the change negative or positive?

The above three issues are transformed into three research questions and on the basis of these issues the present study is designed.

\section{STRUCTURE OF THIS RESEARCH}

This research is composed of five correlated chapters. The first chapter is a general introduction to the entire project. It offers a short summary of the chinese prodemocracy movement in 1989, a brief discussion of the relationship between news media and political movements, the importance and influence of U.S. newspapers, three issues central to this research, and finally, the structure of this research.

Chapter two provides a review of literature in areas related to this research. It is a general survey of previous research and a theoretical foundation on which this research is based. In this chapter, there are three sections: a review of research articles from different journals, a review of theoretical books, and research 
questions.

The third chapter offers a detailed description of the research method. In this research, the method is content analysis. This chapter consists of four sections: the theoretical definition of content analysis, research data, coding categories, and the procedure of data collection.

Chapter four contains research findings and data analysis. Specific charts (Tables) are used to illustrate details of research findings. Findings in each chart are followed by interpretations and analysis.

The last chapter presents a general discussion of this study, a summary of the research findings, conclusion of the research, and implications for future research in this field. Limitations of this research are also discussed in this chapter. The implication section offers some tentative suggestions for future research in this area. 
CHAPTER II

\section{LITERATURE REVIEW}

\section{INTRODUCTION}

This research is an attempt to examine how some of the leading U.S. newspapers portrayed the 1989 pro-democracy movement in China. The literature review provided in this chapter focuses on two major areas related to this topic. The first part provides a discussion on the substantive issues of mass communication. The second is about some relevant theoretical issues in the study of news media and mass movements. Following the literature review, general research questions are posed. At the end of this chapter, specific research questions are presented.

\section{GENERAL ISSUES OF NEWS MEDIA}

\section{What Is News?}

Where does the concept of "news" come from? Edwin (1972), in his writing about the history of American journalism, said that the word "news" was not commonly used until the invention of printing made it possible for the masses to see printed periodicals. Instead, before 1500, the word "tidings" was usually used to refer to current events. In Edwin's words, 
The word "news" was coined to differentiate between the casual dissemination of information and the deliberate attempt to gather and process the latest intelligence (p.3).

From Edwin's writing, we can get a glimpse of the notion that news is not raw information in our daily lives. News is purposely collected, intentionally filtered, and systematically processed information that is intended to fulfill certain purposes. This point will be further discussed later in the "News Collection" part of this chapter.

Despite the long history of "news," no precise definition of "news" has emerged. Even some of the leading theorists in this field have to admit that giving a clear definition of news is no easy job. Romano (1986) wrote:

Easy answers, even off-the-cuff ones, don't jump to mind.... "news," unlike "Maryland" or "pineapple," is a vague word on the cusp between the undefined and the self-contradictory (p.40).

In her doctoral dissertation, Fields (1984) discussed the concept of news when she quoted Alexander who said that news

... can be understood as a continuous processing of raw information that makes the experience of a society comprehensible in terms of more general categories. These categories represent both previously articulated normative guidelines and more general value assumptions about what to expect from social life $(p .20)$.

Alexander's point of view provides a functional definition of news. News is raw information that is 
continuously processed on the basis of general categories. These categories reflect normal guidelines and general social value assumptions that are necessary for people to function in societies.

Early theorists in this field see news as information of interest to the general public. News, as some of the theorists see, is just what happened or is happening in the world. As Romano (1986) noted, "the old-fashioned view that 'news' is simply a mirror placed before reality still lives" (p.39).

However, more theorists in the field of mass communication tend to define "news" from another perspective. They seem to put more emphasis on the hidden meaning of "news." Sigal (1986), in his discussion of news sources, contests that, "... news is not reality, but a sampling of sources' portrayals of reality, mediated by news organizations" (pp.27-28). He further states that, "News is not what happens, but what someone says has happened or will happen" (p.15). Sigal's view of news is supported by other like-minded communication theorists like Carey (1986), Romano (1986) and Howitt (1982).

If we take the assumption that news is not what actually happened or will happen in reality, then, does it mean that news reporting is fiction? This question leads our discussion to the issue of objectivity in news reporting. 
objective News Reporting

objectivity in news reporting has been one of the major areas of discussion in the study of mass communication. On the one hand, in all democratic societies, the very first requirement of news media is to be objective and be accurate as much as possible (Peterson, 1976, pp.86-87). On the other hand, people argue that facts are merely vague ideas that cannot be grasped and presented without interpretations (Romano, 1986. pp.40-41). Furthermore, objectivity in news reporting is like a multi-faceted mirror that gives rise to a number of different interpretations and understandings. Some people turn their attention to the requirement of news reporting as a starting point to analyze the issue of objective news reporting.

Peterson (1976), in writing about requirements of press performance, noted,

The first requirement of the press in contemporary society ... is to provide "a truthful, comprehensive, and intelligent account of the day's events in a context which gives them meaning." This requirement demands that the press be accurate; it must not lie (p.87).

objective news reporting is ideal. But more people seem to be in doubt about the possibility of "being really objective" in the practice of journalistic profession. Sigal (1986) asserted, "No procedure can assure truth or validity or avoid interpretation and bias" (p.15). Fields (1984), in her doctoral dissertation, made a 
similar point when she concluded:

1. "Objectivity" in news production is an actual impossibility.

2. News production results in messages which inevitably contain legitimating (or delegitimating), value-laden connotations (p.86).

Despite the fact that different perspectives exist around the issue of objectivity in news reporting, there seems to be a general agreement that,

objectivity has no bearing whatsoever on the truthfulness or validity of a story. Nor does it mean that the story is free of interpretation or bias. objective reporting means avoiding as much as possible the overt intrusion of the reporter's personal values into a news story and minimizing explicit interpretation in writing up the story (Sigal, 1986, p.17).

Fields (1984) seemed to agree with Sigal when she elaborated on her perspective of objective news reporting. She stated:

Objectivity as a norm is useful to the extent that it ensures some "balance," requires an attempt at impartiality, and negatively sanctions intentional fabrications. An account may be "impartial," in the sense that "both" sides (but not all sides) present their refracted accounts of an event or issue $(p .87)$.

Manoff and Schudson (1986) seemed to support the above standpoint when they pointed out that journalism is not different from other types of storytelling activities. Journalistic work is done on the basis of its own professional guidelines and principles within its own set of sociological, ideological, and literary constraints. When 
journalists make their efforts to be "objective" in their professional practice, they demonstrate their strong sense of formal constraints on their work. These constraints include rules, procedures and traditions that tell them what "objectivity" stands for and when (not always) to invoke it (Manoff and Schudson, 1986, p.6).

It seems that the perspective of impossible objectivity in news reporting is based on two important issues that affect the objectivity in the process of news reporting. one is how we interpret "fact." The other is what factors affect objectivity in news reporting.

What is fact? White (1970) states the problem powerfully:

Although there are innumerable facts, facts, unlike situations or states of affairs, don't exist. A distinction can be drawn between the occurrence of an event or the existence of a state of affairs and the fact that such an event occurred or that such a state of affairs exists. Contrariwise, facts, but not events, situations, or states of affairs, can be disputed, challenged, assumed, or proved. Facts can be stated, whereas events and situations are described. There may be facts about an event, situation, or state of affairs, but none of the latter about a fact (p.80).

Since "fact" can be disputed, challenged, assumed, or proved, objectivity of news reporting cannot escape disputation and challenge.

Another factor that affects objective reporting is news selection. News selection is a continuous complex process that turns raw information into what is called "news" on the 
basis of general categories and under professional

guidelines. News presented to the general public is not raw information that we normally find in daily life. It is filtered, processed, and reshaped information that intends to fulfill certain purposes. For a better understanding of how news selection affects "objectivity" in news reporting, the process of news selection needs to be examined.

\section{News Selection}

Hiebert (1982) provides a discussion of five criteria for news selection: timeliness, proximity, prominence, consequences, and human interest (pp.422-423).

In order to be "news," it has to be timely. As an old cliche goes, "Nothing is as old as yesterday's newspaper." To be more exact, news loses its newsworthiness if it is not timely.

Proximity is also important in news selection. No news is more important than news about events that take place under one's nose. For example, the earthquake in Bay area California a few years ago might have been much more important to the local people than the election of the governor in its neighbor state Nevada.

Prominence never fails to make news because the more prominent the source, the more newsworthy it is. The President of the United States or a movie star is obviously more newsworthy than a waiter or salesman. That explains why the rich and famous frequently become the focus of news 
media.

Consequences have a direct bearing on newsworthiness. An ordinary human being might suddenly become newsworthy by discovering a cure for AIDS because the consequence of his discovery means an end to the fear of that deadly disease.

Human interest is an important aspect in news selection. A large portion of each day's news is selected on the basis of factors like adventure, conflict, humor, pathos and bathos, sex, the odd and the unusual simply because such news is interesting to people.

In Reading The News, Romano (1986) perceived the above five elements of news selection as the traditional way to select news (p.59). In his discussion of news selection, Romano (1986) offered a specific list of things normally covered or not covered in modern newspapers.

The press covers symbolic events, the formerly famous, anniversaries, the possible, tasteful matters, stories that can win it prizes, covers political friends favorably and enemies unfavorably; the press does not cover events if doing so may cause the death of innocents, the press does not report matters that reflect badly on people in its good graces, nor does the press critically examine privileged cultural beliefs (for detailed discussion, see Romano, 1986, pp. 48-59)

"Gatekeeper" is another important concept in the process of news selection. Howitt (1982) said: 
The concept of gatekeeper was about the first major theoretical idea developed to explain the way in which media organizations operate and function (p.19).

A gatekeeper is an individual or a group of people who have the power to decide what is to be included and what is to be excluded before raw information is processed into "news." In this sense, gatekeepers play a key role in the process of news selection. Normally, a gatekeeper is viewed as one individual who makes decisions about what should be printed in the paper. But in reality, almost anybody could function as a gatekeeper, though nobody has to be one.

\section{Public Need For News}

As stated earlier, news is information that has been filtered, processed, and then, presented to the public. News, just as all sorts of information, is vital for everyone to survive, to make judgement, and to deal with the environment. Hiebert (1982) provides a long discussion on human need for information. All human beings need information for one reason or another. Even in primitive times, each tribe sent its best climber to climb the tallest tree to look out for information on which the tribe depended for survival.

In modern societies, people mostly depend on mass media for information they need to survive and function. Journalists in modern societies function like the tree climbers in primitive times. They provide information on 
what is happening in the world, in their own countries, and in our neighborhoods as well.

Besides our need for news to survive and to function in modern society, we also need news and other information to satisfy our desire for knowledge, to satisfy our personal interests, curiosity, and to simply get along in human society. To put it briefly, news as information processed to serve human needs plays a vital part in human survival and social development.

THEORETICAL ISSUES OF MASS MEDIA AND MASS MOVEMENT

\section{Basic Concepts In Mass Communication Theory} as :

The process of mass communication can be simplified Who says what to whom through what channel with what effects.

The process of communication starts with a communicator. The mass communicator, however, differs significantly from the individual communicator in interpersonal communication. Hiebert (1982), in writing about the basic concepts in mass communication, stated:

...the communicator or sender in mass communication is rarely one individual. The people we identify as mass communicators are for the most part only the visible portion of a vast and complex network of people. The mass communicator in American media is usually a complex organization, although individuals at times seem to function as mass communicators (pp.77-78).

The second element is the message. Hiebert (1982) 
employed the concept of "message unit" which involves the interaction of three elements, namely, content, code, and medium .

1. Content is the data, the idea, the substance. It is the communication.

2. Code is the symbol system. And the symbols used have a significant impact on the content. It is communication language.

3. Medium is the organizational structure, the framework on which the ideas are woven. The technology, the tools, the practices, and so forth make each mass medium's expression of the same content different. It is the organization (p.96).

The third, and probably the most important element in mass communication, is the audience. Without a audience, there would be no mass communication, or any other communication at all.

The focus of the entire mass communication process is on its destination -- the audience. Why would a conglomerate communicator send content if it were not for audiences and the reactions of individuals that make up audiences (Hiebert, 1982, p.183).

Unlike the receiver in the interpersonal communication process who is normally an individual, the receiver in mass communication is part of a larger audience (listeners, readers, and viewers).

Tan (1986) discussed the difference between interpersonal communication and mass communication in his writing on communication theories. Besides the differences in communication channel and message effects, one of the special characteristics of mass communication that 
distinguishes it from interpersonal communication is the nature of the receiver in mass communication. According to Tan, Herbert Blumer classified mass audience into three categories: 1) heterogeneous in composition, its members coming from different groups in society; (2) composed of individuals who do not know each other, who are spatially separated from one another, and who cannot interact with one another; and (3) having no leadership or formal organization (Tan, 1986, p.67).

This early definition of "mass society" is the basis of early research that focused on how members of the mass selected their communication and how the "mass" was affected by the media. This perspective views the "mass" as isolated individuals who were passive, unstable, and easily influenced.

However, as Tan (1986) later pointed out:

More recently researchers have discarded the view of "mass audience" as a passive aggregate of disconnected individuals and instead have emphasized social structures or group affiliations among members of the audience, the social nature of most of our contact with the mass media, and the reciprocal nature of media-audience relationships (p.68).

The communication channel is the passage through which a message is sent to the receiver. The channel takes a variety of forms in the process of mass communication. Radio broadcasting sends messages through electric waves, television reaches its audience by similar means like radio does, and newspapers reach their audience by means of 
printed messages on the paper. In short, channels are bridges that connect communicators with audience.

Filters are indispensable for the audience of mass communication to decode the messages they receive. Hiebert (1982) defined filters as:

...the complex mechanisms we use to "decode" messages. Your filters are a part of you; they are learned, and can be relearned. They can be improved, and their improvement can make you a better audience member. Filters are, in effect, frames of references (p.171).

This definition contains two components. First, filters are not something we are equipped with by nature. They can be learned and improved as part of individual growth. Secondly, filters are tools that people utilize to decode communication messages.

According to Hiebert (1982), there are four types of filters that we can learn to use in our daily communication activities.

1. Informational or lingual filters: Each of us has learned a variety of languages and the responses to those codes.

Without accurate informational filters, no positive communication can occur. If you cannot decode the message, you cannot communicate (p.173).

2. Physical filters include two aspects. One is internal physical conditions, and the other is external physical conditions. Internal physical conditions refer to the well-being or health of the individual audience member. A person who is physically ill filters messages differently from the way he or she does in good health.

External physical conditions refer to the environment or surroundings in which we 
receive messages. If the room in which you are reading this book is too hot, too cold, too dark, or too noisy, the environment will affect your senses and the way you filter the content of this page (p.174).

3. Psychological filters are related to our personalities based on each individual experiences. We structure our perception of the world in terms that are meaningful to us, according to our frames of reference, our filters. This process has been described as selective exposure, selective perception, and selective retention (p.176) (for discussion of selective perception and selective exposure, see Schramm, 1973).

4. Cultural filters ... [are] how culture affects the way a person sends or receives messages. (They) are colored, distorted, and polarized by our culture (p.177).

The last element in the mass communication formula is the effects caused by the messages sent from the communicator. The effects of mass communication are measured, in part, by the feedback from the audience.

Many responses to mass communication resemble those in interpersonal communication, such as frowning, yawning, coughing, throwing down the magazine, kicking the TV set, or talking back. But unlike those in interpersonal communication, none of them is observable to the mass communicator because they are all indirect feedback. Again, Hiebert (1982) listed six different types of feedback $(\mathrm{pp} .198-202)$

The first is representative feedback. Since the audience of mass communication is so large and so widely spread, it is impossible to measure feedback from each and 
every audience member. Therefore, a representative sample of the audience is selected for measurement, and the response of the sample is projected scientifically to the whole.

The second is indirect feedback. Mass communicators, like newspaper reporters and performers on TV, rarely receive any direct response from audience members. Usually, the feedback comes from a third party: a rating organization or a polling company.

The third is delayed feedback. In mass communication, feedback from the audience is rarely direct and timely. The delay is caused by a number of factors. Most of all, it occurs because the mass communicator is not in direct touch with the audience. Letters to the editors have to go through the mail. Polls and surveys take time to conduct and study.

The fourth is cumulative feedback. Simply because immediate and individual response from the audience is infrequent, the mass communicator generally accumulates data over a period of time from a variety of sources. Then the data are stored for future use in making decisions regarding what the public wants in the way of media content.

The fifth is quantitative feedback. This refers to reliable numbers of responses from the audience. A mass communicator is more interested in how many people respond than how each individual responds. 
The last is institutional feedback. Mass communication feedback is obtained through large and complex organizations, such as rating companies, polling companies, survey organizations, and so forth. The feedback is institutionalized during the process of being obtained and sent back to the mass communicator.

\section{Effects of Mass Media}

There seems to be a general agreement that mass media have affected the course of human development. At the same time, it is difficult to establish absolute cause-and-effect relationships. Barelson and Janowitz (1966) made the point when they said:

The effects of communication are many and

diverse. They may be short-range or long-run. They may be manifest or latent. They may be strong or weak. They may derive from any number of aspects of the communication content. They may be considered as psychological or economic or sociological. They may operate upon opinions, values, information levels, skills, taste, or overt behavior (p.379).

In fact, the effects of mass media are so diverse that many people feel pessimistic about achieving scientific verification for any aspect of the communication content. However, other people are more optimistic about analyzing the effects of mass media. They view mass media as only one of many factors to be considered in studying the effect of the environment on human behavior. This group of people believe that if the media can be seen as part of the total 
environment that affects people's acts and decisions, a theory for mass media effects might be developed. Defleur (1977) synthesized various theories to arrive at his comprehensive statement:

The effects of a given mass communicated message sent over a given channel will depend upon a large number of psychological characteristics and social category similarities among the members of the audience; these effects will depend upon the kind of social groups within which these people are acting and the relationships that they have with specific types of persons within them; they will depend upon the social norms that prevail among such groups in reality as well as upon the "definitions of the situation" which the communicated messages are to suggest (pp.152-153).

On the basis of Weiss's (1968) collection of research on the effects of mass media of communication, Hiebert (1982) offered a list of the impact of mass media in modern society.

1. The effects of mass media on cognition and comprehension.

2. The effects of mass media on attitude and value change.

3. The effects of mass media on behavioral change.

4. The effects of mass media on children.

5. The effects of violence in the mass media on American society.

6. The effects of erotica in the mass media on American society.

On a broader level, both politically and culturally, especially in the United States, the effects of mass media are real and obvious.

On the political level, the whole watergate phenomenon was a media event because the media participated in the 
political events that led to former President Nixon's resignation. The media had a great deal of impact on those events, and the press significantly affected the process by which the former President was toppled.

The press affects the political agenda setting and decision making. Linsky (1986) has written,

Policymakers generally share the view that among the most significant impacts of the press occur early on the policymaking process, when it is not yet clear which issues will be addressed and what questions will be decided. Officials believe that the media do a lot to set the policy agenda and to influence how an issue is understood by policymakers, interest groups, and the public (p.87).

on the cultural level, the mass media have a significant effect on the changing of American society. The civil rights movement and the women's movement of the past thirty years are, in part, media phenomena that have had a great impact on the entire American society.

The civil rights movement and the women's movement were so powerful that people's value orientation was changed dramatically. Part of the power of these movements came from the news media presentation of the movements. In other words, the news media changed the traditional way to think and look at the American society. And new thinking and new value orientation reinforced the growth of the movements.

\section{Why Do People Communicate?}

Tan (1986) summarized the basic functions of mass communication as an answer to the question of why people 
communicate. On the communicator's part, the function of mass communication is to inform, to teach, to persuade, to please, and to satisfy receiver needs. On the receiver's part, the function of mass communication is (1) to learn of threats and opportunities; to understand the environment; to test reality; to reach decisions; (2) to acquire skills and knowledge necessary to function effectively in the community; to learn appropriate values, behaviors, and roles for acceptance in the community; (3) to enjoy, relax, be entertained, and be distracted from problems and stress (Tan, 1986, pp.69-70).

Bond (1967) made a similar statement tersely in his Introduction to Journalism: "Journalism has four main reasons for being: to inform, to interpret, to guide, to entertain" (p.5).

Mass Media and Political Movements

Political movements or social movements affect the changes in people's attitudes and value orientations. Yet, it is actually the change in people's values and behaviors that result in political movements and social changes. In his discussion of mass media and social change, Tan (1986) wrote:

Social change involves influencing a large number of people so that their "social facts" are altered. The mass media, because they are able to reach large audiences simultaneously, can be effective tools of influence. Thus, mass communication logically and naturally should take a central role in the study of 
social change. Before existing values can be changed, the new values should be made clear to the members of the social units; the mass media could be the vehicles by which these new values are introduced (p.374).

A similar viewpoint is provided by Kielbowiz and

Schever (1986) who stated:

The mass media are one of the major forces that mold and shape social movements, which challenge the established order and prescribe different paths along which change should take place. In certain instances the media have even "become central to life and death" (pp. $71-72)$.

Political movements and social events depend on mass media to send out their messages. In other words, mass media shape and also define political and social movements in the process of reporting and presentation to the public. Gitlin (1980), in his writing about the SDS movement, stated:

-..political movements feel called upon to rely on large-scale communications in order to matter, to say who they are and what they intend to publics they want to sway.... Mass media define the public significance of movement events or, by blanking them out, actively deprive them of larger significance (p.3).

Mass movements have to rely on the power of mass media to define them, to shape them, and create an image to exert influence on any change in society. The power of mass media is such that:

...people find themselves relying on the media for concepts, for images of their heroes, for guiding information, for emotional charges, for a recognition of public values, for symbols in general, even for language (Gitlin, 
1980, p.1).

The above statement suggests that the public perceives and understands a given political movement on the basis of how the mass media define and portray it. In other words, the image of a political movement is created and defined by the mass media.

Media images also become implicated in a movement's self-image; media certify leaders and officially noteworthy "personalities"; indeed, they are able to convert leadership into celebrity, something quite different. The forms of coverage accrete into systematic framing, and this framing, much amplified, helps determine the movement's fate (Gitlin, 1980, p.3).

Since political movements are so much defined and even created by mass media, it becomes necessary to note in what way that mass media shape the image of political movements.

To understand the phenomenon of how mass media "frame" and shape political movements, one important thing is to understand the notion of "media frame" and what role it plays in the process of defining and framing political movements.

Tuchman (1986) synthesized the notion of "media frame" when she wrote, "What makes the world beyond direct experience look natural is a media frame" (p.6). This point is further elaborated by Gitlin (1980) when he said:

Media frames are persistent patterns of cognition, interpretation, and presentation, of selection, emphasis, and exclusion, by which symbol-handlers routinely organize discourse, whether verbal or visual. Frames are principles of selection, emphasis, and 
presentation composed of little tacit theories about what exists, what happens, and what matters (pp.6-7).

Theories of mass communication and social change are general guidelines that provide a broad basis for the present research. The concept of "media frame" has been employed in this study. The relationship between news reporting and the chinese pro-democracy movement in 1989 is explored by using the theories reviewed in this chapter.

\section{Specific Issues of Concern}

The general issue of this research is to show how some leading U.S. newspapers portrayed the 1989 pro-democracy movement in China. Three U.S. newspapers will be examined. They are: The New York Times, Washington Post, and Los Angeles Times. Based on the literature reviewed in this chapter, the following specific research questions are posed.

1. How much attention did the three newspapers give to the chinese pro-democracy movement?

2. How did the three newspapers portray the power struggle on the top level in the Chinese government and the chinese communist party?

3. Has there been any change in the image of China in terms of the symbolic representations used by the three U.S. newspapers during and right after the Chinese pro-democracy movement in 1989?

The following chapter will discuss in detail the methods and techniques employed to address the research questions. 
CHAPTER III

METHOD

INTRODUCTION

Content analysis is employed as the research method in the present study. Holsti (1969) defined content analysis as one of the observational techniques "for making inferences by systematically and objectively identifying specified characteristics of messages" (p.601). The key to this definition is its emphasis on systematic and objective identification of specific items in given messages. Rubin, B., Rubin, M., and Piele (1986) provided a similar definition when they wrote:

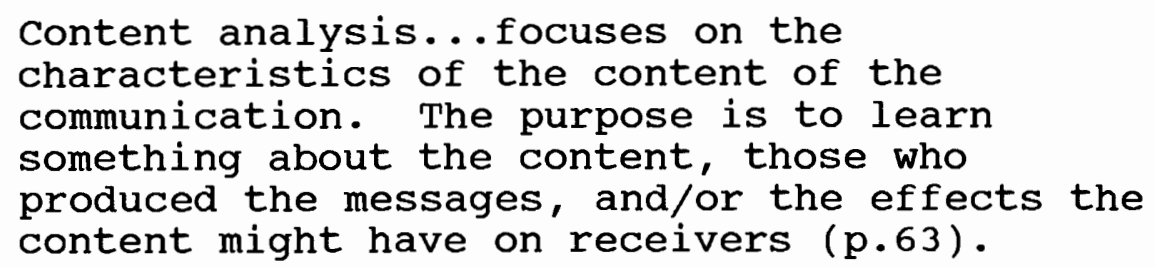

Krippendorff (1980) offered a concise definition which is also useful: "Content analysis is a research technique for making replicable and valid inferences from data to their context" (p.21).

The purpose of content analysis, like all research techniques, is to provide new knowledge, new insights, a representation of "facts," and a practical guide to action. 
Kidder (1986) discussed some of requirements for using content analysis in communication research when he suggested that content analysis requires:

...objectivity of coding categories in order to assure reliability, systematic application of these coding systems across a representative sample of material in order to control observer bias, and consistency in theoretical aims so that the findings can be related to some relevant variable or variables (pp.306-307).

Along with technical requirements for content analysis, Krippendorff (1980) offered a theoretical framework which is based on the following six elements:

1) the data as communicated to the analyst

2) the context of the data

3) how the analyst's knowledge partititions his reality

4) the target of a content analysis

5) inference as the basic intellectual task

6) validity as ultimate criteria of success $(\mathrm{p} .21)$

First, in content analysis, it must be clear which data are analyzed, how they are defined, and from which population they are drawn. Second, the context relative to which data are analyzed must be made explicit. In other words, the analyst must define the boundaries beyond which its analysis does not extend. Third, the analyst's interest and knowledge determine the construction of the context within which inferences are realized. Then, the aim or the target of the inferences must be clearly stated. The basic task of content analysis is to make inferences from available data to certain aspects of the context. 
Conclusions are drawn on the basis of categorized findings. To assure the validity of content analysis, detailed references and sources should be provided and specified so that readers could track and comprehend the results of any given research.

\section{RESEARCH DATA}

The research data were drawn from three "elite" U.S. newspapers. They are: The New York Times, Washington Post, and Los Angeles Times. The first two newspapers were chosen for their established reputation, opinion leadership, and influence in this country and abroad (Semmel, 1977). Los Angeles Times was selected because over the years it had shown consistent news coverage of China (Coffey, 1978).

\section{CODING CATEGORIES}

Each of the three newspapers was coded and analyzed for a period of two months and one week, from April 15, 1989 to June 20, 1989. This time period was selected because it covers the entire pro-democracy movement, including some immediate international media reaction to the violent ending of the "Beijing Incident."

This time period was further divided into four segments to reflect the four closely-connected stages of the prodemocracy movement.

1) April 15, 1989 -- May 3, 1989 (Hu Yaobang's death 
and the seemingly spontaneous student demonstrations);

2) May 4, 1989 -- May 19, 1989 (May 4th Movement Anniversary, Gorbachev's China visit, and the imposition of martial law in Beijing);

3) May 20, 1989 -- June 3, 1989 (escalation of tension and the power struggle on the top level, which contributed to the violent ending of mass demonstrations and students' occupation of Tiananmen Square) ;

4) June 4, 1989 -- June 20, 1989 (the nationwide arrests, executions, international media reaction and the two weeks following the "Beijing incident.") News stories concerning the "Beijing Incident" on the front page of each newspaper were measured by square inches and stories in inside pages of each newspaper were counted as an indicator to show how much attention each newspaper gave to the "Beijing Incident."

The appearance of key Chinese officials in the three newspapers were coded as a possible indicator of the fluctuations in the power struggle at the top level within the Chinese government. The key officials were selected on the basis of how frequently they were mentioned in American news media. These key officials are Deng Xiaoping, Zhao Ziyang, Li Peng, Yang Shangkun, Chen Yun, Wan $\mathrm{li}$, and Li Xiannian. Any of these people, described by any news 
stories either favorably (+1) or unfavorably $(-1)$, were put into one of the following categories:

Losing power -- any individual or group of people described as becoming less powerful, including any unfavorable quotation or mention of denunciation.

Gaining power -- any individual or group of people described as becoming more powerful, including the person's appearance in

favorable background or any favorable quotation.

Finally, the use of any symbolic representations of China was coded to show any possible change in the image of China in the perception of the three newspapers. The symbolic representations are: "Communist China," "Beijing government," "Beijing regime," "Chinese Communist regime," "China," "Chinese government," "PRC," and "mainland China." According to Chang (1989), these symbols could be put into three different categories: ideological, geographical and legal.

Ideological symbols attached ideology to the word, including Communist China, Red China, Chinese Communists, Chinese Communist regime ...they invite emotional associations and private interpretations. Geographical symbols tended to be neutral, showing no political connotations. They were Peking, mainland China.... Legal symbols implied acceptance of legitimacy and existence as a political entity, involving the official title of China: People's Republic of China.... Unlike the ideological symbols, the last two types of symbols tend to be more specific, leaving little room for individual sentiments and projection (p.322).

Any increase in the use of ideological symbols like 
"Communist China" or "Beijing regime," were viewed as a negative change in the image of China in the perception of the three U.S. newspapers. Both positive and negative symbols in each paragraph were only coded once to avoid possible bias associated with individual writing style. However, no positive change of symbolic representation of China was presumed, such as "Democratic China," or "Free China."

PROCEDURE OF DATA COLLECTION

The entire data collection was carried out in two parts with the attempt to assure the reliability of the research method.

In the first part of data collection, a pretest was conducted to anchor the final data analysis. The pretest addressed the first and last research questions (How much attention did each newspaper give to the "Beijing Incident?" Has there been any change in the image of China during the time of the "Beijing Incident?").

The purpose of the pretest was to establish "before" and "after" baselines for the analysis. The pretest was conducted by means of measuring front-page space, counting article numbers, and coding symbols in the three U.S. newspapers for a period of two weeks. The pre-movement period was two months before the pro-democracy movement and the post-movement period was two months after the pro- 
democracy movement. The first period was Feb.5, 1989 -Feb.18, 1989; and the second period was from Aug.6, 1989 -Aug.19, 1989. The pretest was planned and finished before the actual data collection started so that the researcher could establish baselines and be better prepared for certain unforeseen problems and obstacles. The method proved consistent.

The actual data collection started after the pretest was run successfully. One undergraduate and two graduate students were invited to participate in part of the data collection process. Each of them was given detailed instruction regarding how and what to collect. The following principles had to be observed and maintained by all the coders throughout the data collection process:

1) All news stories on the front pages of each newspaper had to be measured and coded. All news stories in inside pages had to be counted. Most of the articles about the pro-democracy movement were carried on front pages, in news sections, and in forum sections. However, some of them were printed in other sections, like the Metropolitan section, the National section, and even in the Living section.

2) Every appearance of key Chinese officials in the three newspapers had to be coded and put into either the "losing power" (-1) or the "gaining power" (+1) category. In case their casting was too ambiguous to 
be put into either of the two categories, it was regarded as no indication of power struggle and, therefore, not coded according to the scheme.

3) Symbolic representations of China, no matter where they were found, had to be coded. Coding units were article paragraphs that contained symbolic representations of China. Paragraphs with no symbols were excluded from the coding process. Symbols in each paragraph, either positive or negative, could be coded only once. Results of coding were then transformed into percentages based on frequency distributions in a given category .

Each coder was required to perform three tasks with premade charts and a standard ruler (see Appendix B). First, each participant counted the number of news stories on the front page and in inside pages. All the news stories on the front page, including photos, were measured with a ruler to determine how much space they occupied on the front page. For example, if a front page story and a photo was 1.25 inch wide and 4 inches long, the photo was 3.75 inches wide and 5.5 inches long, they were coded as 1,1:1.25x4, $3.75 \times 5.5$, and so on. This formula is intepreted as "one news story and one photo, the news story takes up $1.25 \times 4$ square inches and the photo takes up $3.75 \times 5.5$ square inches on the front page." If there were more stories in inside pages, they were counted to obtain a total for each edition 
of each newspaper.

The second task was to identify each appearance of key Chinese officials and record the information on predesigned recording sheets (see Appendix $B$ ). For instance, a news story said, "Li Peng won't stay long." This statement was coded as a negative indicator to show $\mathrm{Li}$ was losing power. Therefore, it was coded as -1 under his name in the recording sheet. If another story said, "Zhao Ziyang seemed to be gaining the upper hand in the power struggle within the communist party," it was coded as +1 in the recording sheet to illustrate a positive indicator of gaining power. The third task that each coder had to perform was to record symbolic representations of China. On the predesigned recording sheets, each label was given a stroke (/) wherever it was found in news stories. Same symbols were only recorded once in each paragraph. Then, the results were transformed into percentages based on frequencies in a given category.

All research tasks were performed on microfilm available at Portland State University. The three newspapers on microfilm are slightly smaller than they actually are. The front page of The New York Times is 18.5 inches long and 11.62 inches wide, with each column measured as 1.86 inches wide. The front page of the Washington Post is measured as 19.3 inches long and 11.4 inches wide. Each column is 1.75 inches wide. The front page of the Los 
Angelas Times is 18.63 inches long and 11.75 inches wide. Each column is 1.75 inches wide.

The following chapter will present research findings and interpretations. 
CHAPTER IV

FINDINGS/ANALYSIS

This chapter presents the research findings and analysis of results. Before analyzing and discussing the research findings, a chronology of the chinese prodemocracy movement from the Los Angeles Times (June 4, 1989) is offered to guide readers through the development of the pro-democracy movement.

\section{CHRONOLOGY}

April 15, 1989: Former Communist Party chief Hu Yaobang dies. Beijing University students put up posters praising him and indirectly criticizing opponents who forced his resignation in early 1987 after student demonstrations in 1986-1987.

April 17, 1989: Thousands of students march in Beijing and Shanghai, shouting," Long live Hu Yaobang! Long live democracy!"

April 22, 1989: While official memorial ceremonies are held for $\mathrm{Hu}$ at nearby Great Hall of the People, students defy police orders to leave the square.

April 26, 1989: People's Daily publishes major Communist party attack on protesters, angering students.

April 27, 1989: More than 50,000 students, with wide support from people on the street, surge past police lines and fill Tiananmen Square, chanting slogans for democracy and freedom. 
April 29, 1989: Officials meet with student leaders, but independent student groups are not satisfied and continue a class boycott at 41 universities.

May 4, 1989: About 100,000 students and supporters march on Tian An Men Square to celebrate the 70th anniversary of China's first student movement. Demonstrations are held in Shanghai, Nanjing and other cities. About 300 journalists protest outside the official New China News Agency.

May 13, 1989: About 2,000 students begin a hunger strike in Tian An Men Square. Number later grows to 3,000.

May 15, 1989: The government deadline for students to leave the square passes. Soviet President Mikhail S. Gorbachev's welcoming ceremony must be moved from the square to the airport.

May 17, 1989: Communist Party chief zhao ziyang pleads for students to leave the square. Students reject his appeal and hold marches that generate 1 million supporters in Beijing.

May 18, 1989: About 1 million people, including many workers, again take to the streets to show their support for the hunger strikers. Premier Li Peng issues a stern lecture to student leaders and refuses to discuss their demands.

May 20, 1989: Martial law is declared in parts of Beijing after zhao reportedly fails to persuade $\mathrm{Li}$ and other hard-liners to compromise. Students resume their hunger strike, then abandon it, saying they need strength for the struggle ahead.

May 21, 1989: Students reject an order by Li Peng to leave Tian An Men Square or face military action. Defying martial law, hundreds of thousands of people remain in the square or block intersections to prevent troops from reaching it.

May 25, 1989: Li makes his first appearance since declaring martial law. State-run radio 
says 27 of 29 provinces support martial law, and military units announce they support martial law.

May 27, 1989: Beijing student leaders propose that students end their occupation of Tian An Men Square. Non-Beijing students resist and the sit-in continues.

May 30, 1989: Students unveil their "Goddess of Democracy," a replica of the Statue of Liberty, on the square. The government calls it an insult to the nation.

June 1, 1989: The Beijing municipal government warns foreign journalists that under martial law they must receive approval for all press coverage. Coverage of the demonstrations is banned.

June $3-4,1989$ : Tens of thousands of troops make several attempts to move on the square but are driven back by crowds of hundreds of thousands of people supporting the students. Riot squads beat and fire tear gas at demonstrators. A final push is made the evening of June 3 , and soldiers begin firing on crowds. Troops surround and enter the square in the early morning hours of June 4 and thousands of protesters flee. Many are killed and hundreds are wounded (Los Angeles Times, June 4, 1989, Part A, p.8).

The 1989 Chinese pro-democracy movement lasted about six weeks, from mid-April to early June, 1989. During this period of time, abundant information concerning the chinese pro-democracy movement was carried in The New York Times, Washington Post, and the Los Angeles Times.

As stated in the previous chapters, there are three major concerns in the present research: (1) How much attention did the movement receive from the three newspapers? (2) How did the three newspapers represent the power struggle in the Chinese government? (3) Has there 
been any change in the image of china in terms of symbolic representations used by the three newspapers? On the basis of these three research questions, the research findings can roughly be categorized as 1) Movement coverage; 2) Power struggle; 3) Change in the image of China.

\section{MOVEMENT COVERAGE}

Table I illustrates findings of the pretest (the premovement period), from Feb.5, 1989 to Feb.18, 1989. A total of twelve news stories and four photos were found and coded in the three newspapers.

\section{TABLE I}

$$
\text { PRE-MOVEMENT -- } 2 / 5 / 89 \text { to } 2 / 18 / 89
$$

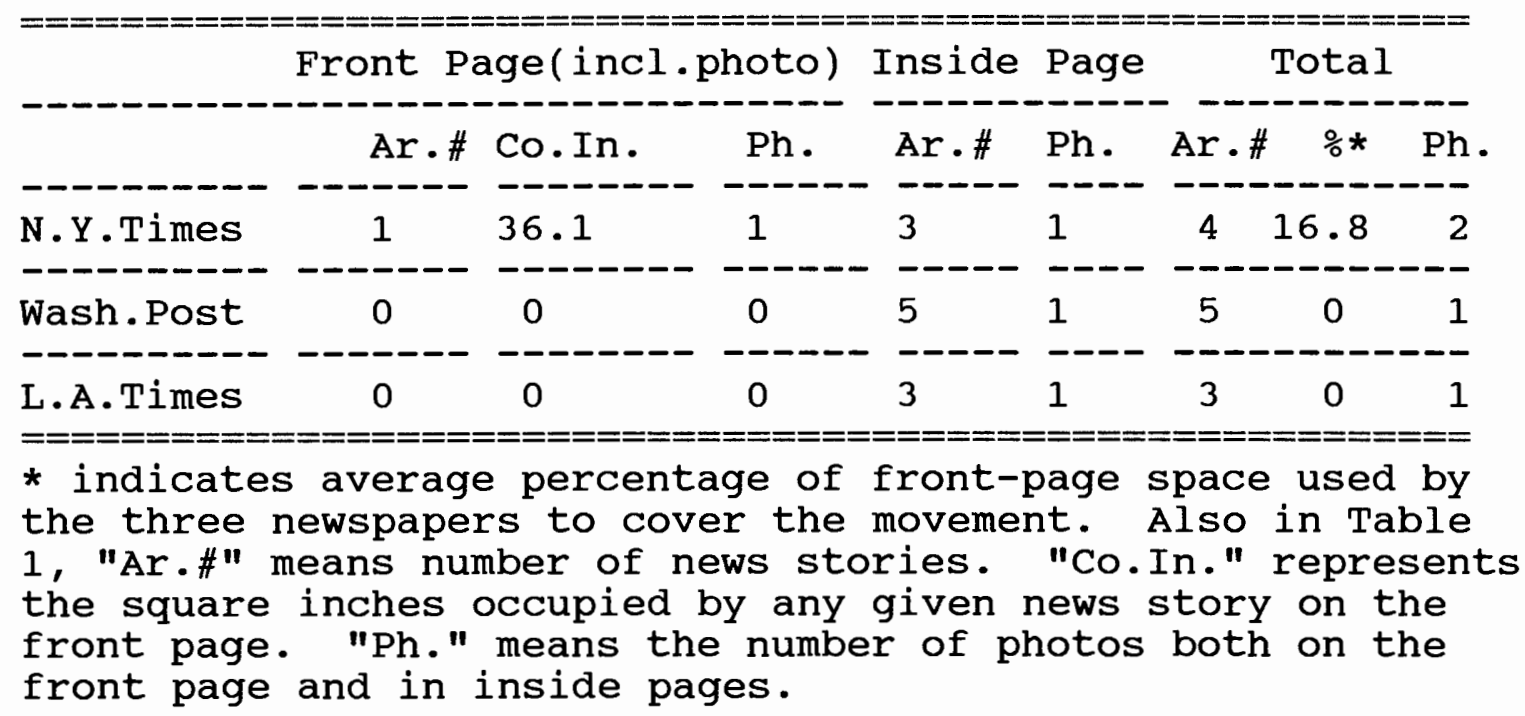

As Table I shows, The New York Times is the only paper that carried one front-page story and one photo on its front page during the pre-movement period. Together, the news 
story and the photo on the front page take up 36.06 square inches, which is $16.8 \%$ of the total front-page space.

on the microfilm, the total daily front-page space in The New York Times is 215 square inches, 232.1 square inches in Washington Post, and 218.8 square inches in Los Angeles Times.

Both Washington Post and Los Angeles Times carried one photo, five and three news stories respectively in their inside pages. As the Chinese pro-democracy movement was unfolding, the front-page coverage of the movement in both Washington Post and Los Angeles Times began to increase rapidly

Table I shows general news coverage of events related to china under normal circumstances. It covers a period of two weeks time which is two months before the pro-democracy movement began (Feb.5, 1989 -- Feb. 18, 1989). This table provides a comparison for the formal research period in the sense that it allows the readers to see the difference of news coverage of the movement at normal times and under extreme circumstances.

After the pro-democracy movement began in late April 1989, news coverage of events related to the chinese prodemocracy movement saw a dramatic increase in all three U.S. newspapers. Table II shows the findings regarding news coverage of the pro-democracy movement (April 15, 1989-June 20, 1989), followed by Table III, a summary of the findings. 
TABLE II

MOVEMENT COVERAGE

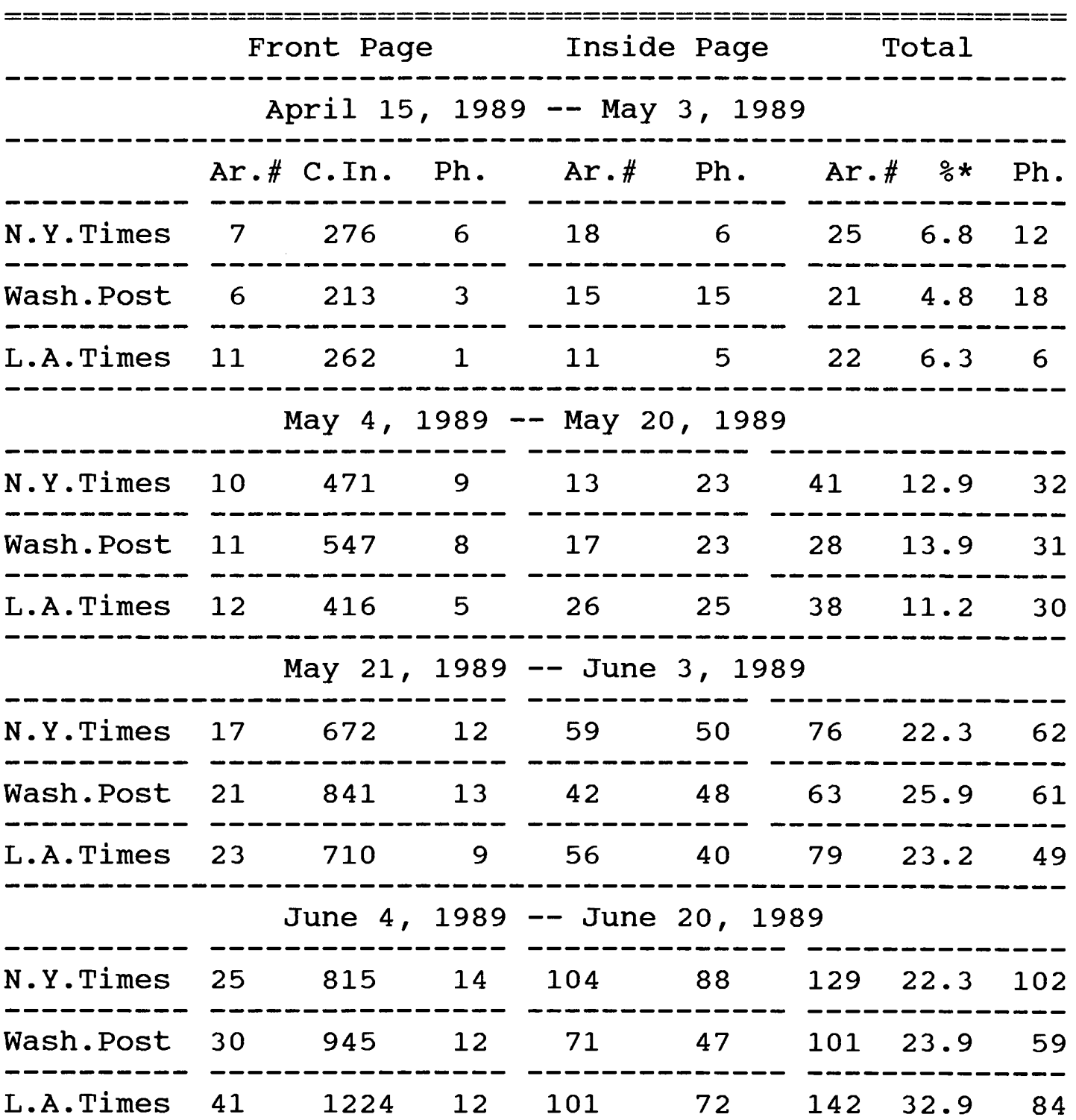

$===========================================$ * indicates average percentage of total front-page space used in the movement coverage.

On microfilm, the front page space of each newspaper is: The New York Times: 18.5 inches by 11.6 inches, with six column of 1.86 each in width; Washington Post: 19.3 inches by 11.4 inches, with six column of 1.75 each in width; Los Angeles Times: 18.63 inches by 11.75 inches, with six column of 1.75 each in width.

Table II shows, in the first research period, Los 
Angeles Times printed more front-page stories than did The New York Times and Washington Post. But The New York Times used a little more of its front-page space and Washington Post printed more photos than did the other two newspapers. The total front-page space used in The New York Times is slightly more than the other two papers.

In the second study period, Los Angeles Times carried more front-page stories than did the other two papers. Washington Post came out first in terms of front-page space used to cover the movement. As for the photos are concerned, The New York Times printed a few more than the other two papers did.

In the third study period, Washington Post devoted more of its front-page space in the movement coverage than did the other two newspapers. Again, The New York Times carried more photos. Los Angeles Times took the lead in terms of the number of front-page stories carried in this study period.

In the last study period, Los Angeles Times outnumbered the other two newspapers in both front-page space usage and the number of news stories on the front page. The New York Times printed more photos on its front page and in its inside pages.

Findings illustrated in Table II indicates all three newspapers paid a great deal of attention to the development of the pro-democracy movement in China. They all used large 
sections on their front pages to report the events and activities in china. The number of photos printed in this period of time is overwhelming compare to the pre-movement period (Feb.5, 1989 -- Feb.18, 1989). Table III is a summary of the news coverage of the pro-democracy movement from April 15, 1989 to June 20, 1989.

TABLE III

SUMMARY OF MOVEMENT COVERAGE -- 4/15/89 to $6 / 20 / 89$

\begin{tabular}{|c|c|c|c|c|c|c|}
\hline \multirow{2}{*}{------} & \multicolumn{2}{|c|}{ Front Page } & \multicolumn{2}{|c|}{ Inside Page } & \multicolumn{2}{|c|}{ Total } \\
\hline & Ar.\# & C.In. & Ar.\# & $\mathrm{Ph}$. & Ar.\# & $\mathrm{Ph}$. \\
\hline Y.Times & 59 & 2234 & 212 & 167 & $271 \quad 15.7$ & 208 \\
\hline ash.Post & 68 & 2546 & 145 & 133 & 21316.6 & 16 \\
\hline A.Times & 87 & 2612 & 194 & 142 & 28118.1 & 169 \\
\hline \multicolumn{7}{|c|}{$\begin{array}{l}\text { * indicates average percentage of each paper's front-page } \\
\text { coverage of the movement in the entire period of data } \\
\text { collection. } \\
\text { The total front-page space of each newspaper is: } 14405 \\
\text { square inches (The New York Times), } 15551 \text { square inches } \\
\text { (Washington Post), and } 14660 \text { square inches (Los Angeles } \\
\text { Times). }\end{array}$} \\
\hline
\end{tabular}

Table III contains two noticeable things: 1) Los Angeles Times is in the leading position regarding the number of front page stories, front page space, number of total news stories, and total front page space used to report the prodemocracy movement; 2) The New York Times printed far more photos on its front page and also in its inside pages than did the other two papers.

All three newspapers returned to their normal foreign 
news coverage after the pro-democracy movement was suppressed by force in early June, 1989. Table IV shows the news coverage of events in China two months after the prodemocracy movement (Aug.6, 1989 -- Aug.19, 1989).

\section{TABLE IV}

$$
\text { POST-MOVEMENT -- } 8 / 6 / 89 \text { to } 8 / 19 / 89
$$

\begin{tabular}{|c|c|c|c|c|c|c|c|}
\hline & Front & Page ( & (incl.Ph) & Inside & Page & Tot & al \\
\hline & Ar.\# & Co.In. & $\mathrm{Ph}$ & Ar.\# & $\mathrm{Ph}$. & Ar.\# & $\% *$ \\
\hline N.Y.Times & 1 & 19.3 & 0 & 7 & 0 & 8 & 0.6 \\
\hline Wash.Post & 1 & 17.3 & 0 & 11 & 0 & 12 & 0.5 \\
\hline L.A.Times & 3 & 45.2 & 0 & 10 & 4 & 13 & 1.5 \\
\hline
\end{tabular}

News coverage shown in Table IV is moderately higher than the findings in Table $I$, the pre-movement period. Los Angeles Times leads The New York Times and Washington Post in terms of front-page coverage, number of front-page news stories and number of inside page stories.

Findings of the entire research period, including premovement and post-movement period demonstrate the consistency of Los Angeles Times in covering the events related to china. This result conforms with the result of the research conducted by Coffey, which concluded that Los Angeles Times had shown consistent news coverage of China over the years (Coffey, 1978). 
POWER STRUGGLE

Table I shows the power struggle within the Chinese government before martial law was declared in Beijing on May 20,1989 .

\section{TABLE V}

\section{POWER STRUGGLE -- $5 / 5 / 89$ to $5 / 19 / 89$}

\begin{tabular}{|c|c|c|c|c|c|c|c|c|}
\hline \multirow{3}{*}{ 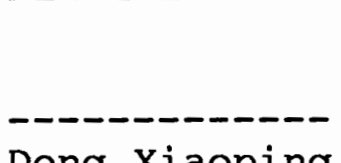 } & \multicolumn{2}{|c|}{ N.Y.Times } & \multicolumn{2}{|c|}{ Wash.Post } & \multicolumn{2}{|c|}{ L.A.Times } & \multicolumn{2}{|c|}{ Total } \\
\hline & + & & + & - & + & - & + & - \\
\hline & 5 & 11 & 2 & 3 & 3 & 2 & 10 & 16 \\
\hline Zhao Ziyang & 21 & 4 & 3 & 6 & 2 & 1 & 26 & 11 \\
\hline Li Peng & 4 & 16 & 10 & 3 & 4 & 9 & 18 & 28 \\
\hline Yang shangkun & 1 & 1 & 2 & 0 & 1 & 0 & 4 & 1 \\
\hline Chen Yun & 0 & 0 & 0 & 0 & 0 & 0 & 0 & 0 \\
\hline Wan $\mathrm{Li}$ & 0 & 0 & 0 & 0 & 0 & 0 & 0 & 0 \\
\hline Li Xiannian & 0 & 0 & 0 & 0 & 0 & 0 & 0 & 0 \\
\hline
\end{tabular}

The above table illustrates the research findings concerning power struggle within the Chinese government perceived by the three U.S. newspapers before martial law was imposed in Beijing. As far as the power struggle is concerned, the attention of the three U.S. newspapers mainly focus on the first three officials on top of the list, namely, Deng Xiaoping, Zhao Ziyang, and Li Peng.

The total figure shows that Zhao was winning the power struggle (+26 vs. -11$)$, and both Deng and Li were losing $(+10$ 
vs. $-16 /+18$ vs. -28$)$. The New York Times carried more stories favorable to zhao rather than negative $(+21$ vs. -4$)$. Washington Post is the only paper that perceived $\mathrm{Li}$ as winning the power struggle $(+10$ vs. -3$)$. President yang Shangkun received little attention and was perceived as gaining power (+4 vs. -1$)$.

Power struggle caught the attention of news media after People's Daily denounced the student demonstration on April 26,1989 . The top Chinese officials were divided into two groups around the issue of what attitude should be adopted towards the student demonstration and their demands for more freedom and democracy. Premier Li Peng, representing a group of aged leaders, was firm and harsh to the students. His rough attitude was most public when he met with student representatives in the Great Hall of the People and refused to consider their demands.

on the contrary, the party leader zhao Ziyang was conciliatory to the demonstrators. He was all tears in Tiananmen square when he was talking for the last time to the people on the square. He tried to persuade students to leave the square and seek solutions to solve problems through legal channels. But his proposal found few supporters on the square.

Under normal circumstances, the party leader was supposed to be the highest ranking official in decision making. So, the party leader, zhao Ziyang, was the person 
to declare martial law. Yet, Zhao did not show up in the meeting at which premier Li Peng declared martial law.

Al1 three newspapers, based on reports from their correspondents in China, provided readers with many inconsistent predictions about the power struggle in the Chinese government. But that seems to be the best they could because many news reports could not be confirmed when chaos existed in every major city in China. An Asian diplomat put it this way,

China has been in turmoil and without any effective central government since Prime Minister $\mathrm{Li}$ and President Yang summoned army troops to the capital on Saturday morning to suppress the nation's democracy movement (Kristof, 1989).

As Table VI illustrates, the confusion in China remained unclear until the end of the movement.

TABLE VI

POWER STRUGGLE -- $5 / 20 / 89$ to $6 / 4 / 89$

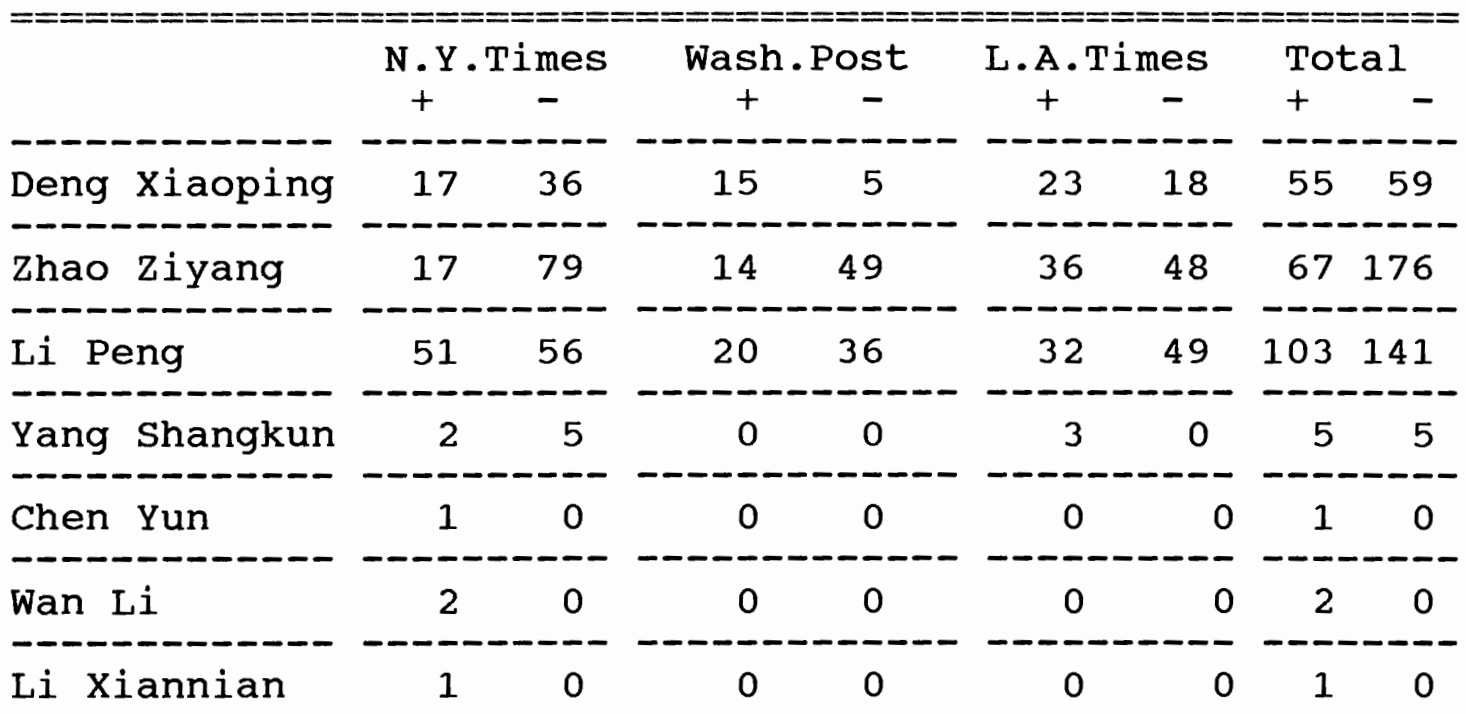


The above table illustrates the three newspapers' perceptions of the power struggle in the Chinese government after martial law was imposed in Beijing on May 20, 1989.

In the second research period concerning the power struggle in the Chinese government, both Zhao Ziyang and Li Peng were perceived as losing power. Compared to both thao and $\mathrm{Li}$, Deng Xiaoping received more positive comments and descriptions from Los Angeles Times (+23 vs. -18) and Washington Post $(+15$ vs. -5$)$.

Throughout the research period on power struggle, Chen Yun (Chairman of the Central Consultative Committee), Wan Li (Head of the National People's Congress), and Li Xiannian (former President) were given little attention from the three newspapers. Overall, according to the press, it seemed nobody was winning the power struggle. As one of the news stories in The New York Times says, "Beijing creates a no-win situation" (The New York Times, May 23, 1989, p. A29).

\section{CHANGE IN THE IMAGE OF CHINA}

Table VII shows symbolic representations of China before the pro-democracy movement took place in April, 1989. In all three newspapers, "China" is the most often used symbol to refer to china. The percentage of use of other symbols to represent China is very low. In all three newspapers, the use of ideological symbols did not pass $5 \%$, with an average 
of only $2 \%$. "Beijing" was used more than any other symbol except "China." All in all, 90 paragraphs were coded in this pre-movement period. In this period, over $85 \%$ of the time the three newspapers used "China" to refer to China. China's official title, the People's Republic of China, was used only a little more than two percent.

TABLE VII

IMAGE OF CHINA -- $2 / 5 / 89$ to $2 / 18 / 89$

\begin{tabular}{|c|c|c|c|c|c|c|}
\hline & $\begin{array}{l}\text { Communist* } \\
\text { China }\end{array}$ & PRC** & $\begin{array}{l}\text { Mainland } \\
\text { China }\end{array}$ & China & Beijing & $\mathrm{N} * * *$ \\
\hline$------\cdots--$ & $----\cdots$ & $-\cdots-\cdots$ & ----- & & & \\
\hline N.Y.Times & $1 \%$ & $2.7 \%$ & $3.8 \%$ & $82.9 \%$ & $11.5 \%$ & 20 \\
\hline 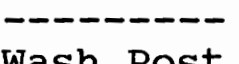 & 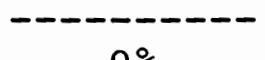 & --- & $-\cdots$ & $-x--$ & - & \\
\hline Wash. Post & $0 \%$ & $2 \%$ & $0 \%$ & $90 \%$ & $8 \%$ & 39 \\
\hline L.A.Times & $5 \%$ & $2.5 \%$ & $0 \%$ & $85 \%$ & $7.5 \%$ & 31 \\
\hline Total & $2 \%$ & $2.4 \%$ & $1.3 \%$ & $85.9 \%$ & $9 \%$ & 90 \\
\hline
\end{tabular}

* This symbol includes Communist China, Beijing regime, Deng's regime, Chinese Communists, Chinese Communist regime, Red China, and the Chinese totalitarianism.

** PRC: People's Republic of China.

***Entries are number of Paragraphs. Paragraphs with no symbols are excluded.

Table VIII illustrates the overall change in the image of China perceived by the three U.S. newspapers. In aII three newspapers, there is a gradual increase in the use of ideological symbols to refer to china as the Chinese prodemocracy movement developed. As Table VIII shows, the use of ideological symbols increased dramatically after martial law was imposed in Beijing on May 20, 1989. 
TABLE VIII

CHANGE IN THE IMAGE OF CHINA

The New York Times

\begin{tabular}{|c|c|c|c|c|c|c|}
\hline & $\begin{array}{c}\text { Communist* } \\
\text { China }\end{array}$ & PRC** & $\begin{array}{c}\text { Mainland } \\
\text { China }\end{array}$ & China & Beijing & $\mathrm{N} * \star *$ \\
\hline $4 / 15--5 / 3$ & $6.4 \%$ & $1.6 \%$ & $0.7 \%$ & $68.1 \%$ & $23.2 \%$ & 84 \\
\hline 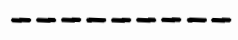 & -5 & -0 & & -- & & \\
\hline $5 / 4--5 / 19$ & $8.3 \%$ & $3.3 \%$ & $1.7 \%$ & $65.6 \%$ & $21.1 \%$ & 160 \\
\hline $5 / 20--6 / 3$ & $10.7 \%$ & $1 \%$ & $1.1 \%$ & $72.7 \%$ & $14.5 \%$ & 315 \\
\hline$-2--1--$ & 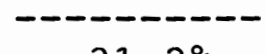 & -- & & & & \\
\hline $6 / 4--6 / 20$ & $31.2 \%$ & $2.4 \%$ & $0.8 \%$ & $55.8 \%$ & $9.8 \%$ & 467 \\
\hline otal & $20 \%$ & $2 \%$ & $1 \%$ & $63 \%$ & $14 \%$ & 1026 \\
\hline
\end{tabular}

Washington Post

\begin{tabular}{lcccccr}
\hline $4 / 15--5 / 3$ & $11 \%$ & $2.2 \%$ & $0 \%$ & $66.9 \%$ & $19.9 \%$ & 78 \\
\hline $5 / 4--5 / 19$ & $15.4 \%$ & $0.8 \%$ & $0 \%$ & $66.7 \%$ & $17.1 \%$ & 113 \\
\hline $5 / 20--6 / 3$ & $18.7 \%$ & $2.5 \%$ & $2.1 \%$ & $62.3 \%$ & $14.4 \%$ & 135 \\
\hline $6 / 4-6 / 20$ & $25.7 \%$ & $1.4 \%$ & $0.8 \%$ & $59.2 \%$ & $12.8 \%$ & 477 \\
$-T o t a 1$ & $21.8 \%$ & $1.7 \%$ & $1 \%$ & 59.8 & $15.7 \%$ & 803
\end{tabular}

Los Angeles Times

\begin{tabular}{lccccrr}
\hline $4 / 15--5 / 3$ & $2 \%$ & $2 \%$ & $1 \%$ & $73.3 \%$ & $21.7 \%$ & 49 \\
\hline $5 / 4--5 / 19$ & $3.8 \%$ & $1.4 \%$ & $0.5 \%$ & $70.2 \%$ & $24.1 \%$ & 175 \\
\hline $5 / 20--6 / 3$ & $14.3 \%$ & $0.8 \%$ & $1.1 \%$ & $72.1 \%$ & $11.7 \%$ & 224 \\
\hline $6 / 4-6 / 20$ & $27.2 \%$ & $1.1 \%$ & $5 \%$ & $58.7 \%$ & $12.5 \%$ & 456 \\
-0 Tal & $19.6 \%$ & $1 \%$ & $0.6 \%$ & $64.1 \%$ & $14.7 \%$ & 904
\end{tabular}

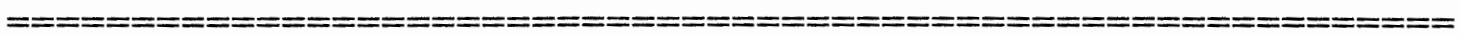

* This symbol includes Communist China, Beijing regime, red China, Deng's regime, Chinese Communists, Chinese Communist regime, and the chinese totalitarianism.

** PRC: People's Republic of China

*** Entries are numbers of paragraphs. Paragraphs with no symbols are excluded.

The first part of Table VIII shows how The New York 
Times used different symbols to represent China in the entire research period.

Basically speaking, the percentage of use of "PRC" and "Mainland China" did not change from the percentage in the pre-movement period (compared to Table VII). But the percentage of ideological symbols increased to $10.7 \%$ before the Chinese government used army troops to retake Tiananmen Square on June 4, 1989. After violence occurred, the use of ideological symbols jumped to $31 \%$, a $25 \%$ increase compared to the first study period. At the same time, the use of "China" dropped from $68.1 \%$ in the first study period to $55.8 \%$ in the last study period, a noticeable $12 \%$ decrease. If compared to the pre-movement period (see Table VII), the use of "China" decreased more than $30 \%$ at the end of the pro-democracy movement. In addition, the use of "Beijing" dropped from $23.2 \%$ to $9.8 \%$, a $13 \%$ decrease.

A total of 1026 paragraphs in The New York Times were coded. The findings show that "Communist China" (including all other ideological symbols) was used $20 \%$ of the time, "China" was used $63 \%$ of the time, and "Beijing" was used $14 \%$ of the time. Compared to the pre-movement period, The New York Times increased by ten times the use of ideological symbols to represent China.

The result seems to show a negative change in the image of China, in the perception of The New York Times. Also, the negative change in the image of China seems to be 
supported by the findings of decrease in using general symbols like "China" and "Beijing."

The second part of Table VIII shows symbolic representations used in Washington Post to refer to China.

The percentage of using ideological symbols in Washington Post increased steadily from $11 \%$ and $15.4 \%$ before martial law was declared to $25.7 \%$ after violence took place in Beijing. The increase is over $25 \%$ if compared to the pre-movement period, which is $0 \%$. At the same time, the use of general symbols, "China" and "Beijing," dropped from $66.9 \%$ to $59.8 \%$ and from $19.9 \%$ to $12.8 \%$ respectively.

A total of 803 paragraphs are coded from Washington Post, and findings show that an average of $21.8 \%$ use of ideological symbols, $75.5 \%$ use of general symbols ("China" and "Beijing" combined).

A comparison with the pre-movement findings (see Table VII) shows that, in Washington Post, the use of ideological symbols increased $25 \%$ and the use of general symbols ("China" and "Beijing") decreased more than $30 \%$ over the time.

This finding seems to indicate a negative change in the image of China took place during the pro-democracy movement, especially after army troops cleared the Tiananmen square by force on June $4,1989$.

The use of other symbols did not show much change throughout the research period. 
The third part of Table VIII illustrates findings of symbolic representations of China used in Los Angeles Times.

Los Angeles Times used relatively fewer ideological symbols before martial law was imposed in Beijing (3.8\%). After declaration of martial law in Beijing, the use of 61 ideological symbols increased rapidly to $14 \%$ and reached $27 \%$ after violence took place in Beijing.

The use of general symbols, "China" and "Beijing," decreased from $73 \%$ to $58.7 \%$ and $21.7 \%$ to $12.5 \%$ respectively. There is no significant change in the use of other symbols ("PRC," and "Mainland China").

A total of 904 paragraphs are coded from Los Angeles Times in the entire research period. Findings show 19.6\% use of ideological symbols and $78.8 \%$ use of general symbols ("China" and "Beijing" combined).

If the above findings are compared with the findings in the pre-movement period (Table III), the use of ideological symbols in Los Angeles Times increased $22 \%$, from $5 \%$ to $27 \%$. And the use of general symbol (China) decreased dramatically from $85 \%$ in the pre-movement period to $58.7 \%$ in the last study period.

Findings regarding the use of symbolic representations of China in Los Angeles Times seems to confirm the findings about the other two newspapers' use of symbolic representations of China. Findings on using symbolic 
representations of China in Los Angeles Times, like in the other two newspapers, seems to show a negative change in the image of China during the time of the Chinese pro-democracy movement in 1989, especially after the chinese government used army troops to regain control of the situation in the capital on June 4, 1989.

Finally, Table 4 (post-movement) is presented to show the use of symbolic representations of China two months after the pro-democracy movement in china.

\section{TABLE IX}

IMAGE OF CHINA -- $8 / 6 / 89$ to $8 / 19 / 89$

\begin{tabular}{|c|c|c|c|c|c|c|}
\hline & $\begin{array}{l}\text { Communist* } \\
\text { China }\end{array}$ & PRC** & $\begin{array}{c}\text { Mainland } \\
\text { China }\end{array}$ & China & Beijing & $\mathrm{N} * * *$ \\
\hline N.Y.Times & $1.4 \%$ & $1.1 \%$ & $1.5 \%$ & $83.1 \%$ & $12.9 \%$ & 56 \\
\hline-------- & & & & & & \\
\hline Wash.Post & $7.5 \%$ & $3.5 \%$ & $0 \%$ & $58.7 \%$ & $30.3 \%$ & 83 \\
\hline L.A.Times & $4.4 \%$ & $0 \%$ & $0 \%$ & $71.7 \%$ & $23.9 \%$ & 36 \\
\hline Total & $4.4 \%$ & $1.5 \%$ & $0.5 \%$ & $71.2 \%$ & $22.4 \%$ & 175 \\
\hline
\end{tabular}

* This symbol includes Communist China, Beijing regime, red China, Deng's regime, Chinese Communists, Chinese Communist regime, and Chinese totalitarianism. ** PRC: People's Republic of China ***Entries are number of paragraphs. Paragraphs with no symbols were excluded.

In Table IX, the use of ideological symbols dropped an average of $15 \%$, from $20 \%$ after martial law to $4.4 \%$. The use of general symbols in all three newspapers increased an equal percentage, from 75\% to 95\% ("China" and "Beijing" combined). 
Findings in Table IX (post-movement period) indicate that all three newspapers dramatically decreased their use of ideological symbols and increased their use of general symbols to refer to China. Although the percentage of using all symbolic representations of China have not returned to 63 what they used to be in the pre-movement period, the fluctuation is significant enough to show the dramatic ups and downs of using symbolic representations of China in the three newspapers during the time of the Chinese prodemocracy movement in 1989.

Findings of the present research seems to suggest three things: 1) all three newspapers increased their coverage of events in China dramatically during the Chinese pro-democracy movement from April 15, 1989 to June 20, 1989; 2) the three top officials in the chinese government were perceived as losing power, except one period in which the party leader Zhao Ziyang was seen as gaining power and another period in which Deng Xiaoping was viewed as gaining power; 3 ) the image of China changed in the negative way all along, especially after the chinese government used military troops to regain control in the capital.

The next chapter contains conclusion of the present research and implications for future research in this field. 


\author{
CHAPTER V \\ CONCLUSION/IMPIICATIONS
}

\title{
INTRODUCTION
}

The present research is an attempt to shed some light on how some of the leading U.S. newspapers portrayed the 1989 Chinese pro-democracy movement. The total research period covers six months, from early Feb. 1989 to mid Aug. 1989, including the pretest period (pre-movement and postmovement) .

This study focuses mainly on three aspects regarding how the chinese pro-democracy movement was portrayed by some of the leading U.S. newspapers. The first part of interest concerns how much attention the pro-democracy movement received from the three leading newspapers in the United States. The second aspect regards the power struggle on the top level of the chinese government in the perception of the three U.S. newspapers. The last section of research focuses on the change in the image of China in the perception of the three U.S. newspapers during and right after the Chinese prodemocracy movement in 1989.

These three aspects of interest were developed into three research questions on the basis of literature review. Content analysis was employed as the research method to 
explore the three research questions. Three leading U.S. newspapers were selected for analysis (The New York Times, Washington Post, and Los Angeles Times). Each newspaper was treated with the same research method and all news articles were analysed and coded. The data collection sheets were all predesigned and copied before the start of actual data collection. Findings on the three research questions are presented by using presentation tables (see the previous chapter).

\section{SUMMARY OF RESEARCH FINDINGS}

In all three newspapers, a division seems to exist between the first two research periods (before martial law was imposed in Beijing on May 20, 1989) and the last two periods (from May 21, 1989 to June 20, 1989) in terms of how much front-page space was used in each newspaper to cover the Chinese pro-democracy movement. Before martial law was declared in Beijing on May 20, 1989, the rise of the frontpage coverage in The New York Times was gradual, from $6.8 \%$ to 12.9\%. The Washington Post reached $13.9 \%$, the highest in the first two study periods. The Los Angeles Times saw an increase from $6.3 \%$ to $11.2 \%$.

In the third study period, the percentage of front-page coverage in all three U.S. newspapers jumped dramatically. The New York Times saw a rise of $9.4 \%$ from its previous $12.9 \%$. The percentage of front-page space in washington 
Post reached $25.9 \%$ from its previous $13.9 \%$. The Los Angele Times more than doubled its previous percentage of $11.2 \%$ and reached $23.2 \%$, highest in the third study period. In the last study period (June 4, 1989 -June 20, 1989), Los Angeles Times used $32.9 \%$ of its front-page space to cover the events and activities in china. In the same study period, the percentage of front-page space in both The New York Times and Washington Post did not see much fluctuation except that the percentage in Los Angeles Times rose another $9.7 \%$

In all three newspapers, front-page coverage of events in China began to dwindle after June 13, 1989, one week after the chinese authorities used troops to retake Tiananmen Square from demonstrators who occupied the square for more than one month. Two months after the chinese government gained total control of the situation, all three newspapers dropped their front-page coverage on events in China to less than $1 \%$, though they all did some follow-up reporting in their inside pages.

Power struggle at the top level of the Chinese government began to attract the attention of the three U.S. newspapres after the May 4 th Movement anniversary, especially during the time when Gorbachev visited China in mid-May, 1989. The focus of intense power struggle within the Chinese government was mainly on the top three officials on the list, Deng Xiaoping, Zhao Ziyang, and Li Peng. The 
rest of the chinese officials received relatively less attention. This finding seems to indicate two things: first, all three newspapers were cautious when they were trying to surmise what was going on in the chaotic situation in Beijing; second, not very much was known about what role the other four officials (see Table V) were playing in the power struggle, important as they were behind the scene. None of the three newspapers was consistent in its reports as to who was winning the power struggle before military forse was used by the chinese government to regain control of the situation in Beijing on June 4, 1989. One reporter said that rumors were dominant at the time. The situation in China was so chaotic and confusing that many news reports were merely based on hearsay and even on pure rumors. It was often the case during that period of time that one news story predicted that Li peng was losing the power struggle and soon would be thrown out as a scapegoat, and then, another story in the next day's paper predicted just the opposite.

Overall, the power of the three key Chinese officials was seen as waning. Due to the confusion in China at that time, it was awfully difficult for anybody to say for sure who would eventually win the struggle for power to rule China. However, The New York Times saw the party leader Zhao ziyang as gaining power and the other two, Deng and Li, as losing in the first study period (May 5, 1989 -- May 19, 
1989). The Washington Post viewed Li Peng as winning the power struggle. In the second study period (May 20, $1989--$ May June 4, 1989), all three top officials were seen as losing power. The Washington Post viewed $\mathrm{Li}$ Peng as gaining power as opposed to the other two in the first study period and all three were viewed as losing power in the second study period. And Los Angeles Times saw all three top officials as losing power in both study periods.

Power struggle at the top level of the chinese government remained unclear until one week after military troops were ordered to clear the demonstrators out of Tiananmen Square and Deng and $\mathrm{Li}$ were seen on TV congratulating army officers on their successful mission. The three U.S. newspapers showed a similar pattern in using symbols associated with China. There seems a clearcut difference between the first three study periods (April 15, 1989 -- June 3,1989 ) and the last one (June 4, 1989 -June 20, 1989). Before military troops were used in Beijing on June 4, 1989, China was often identified as either "China" or "Beijing," though the use of ideological symbols also increased steadily. After Tiananmen Square was cleared by military force, the use of ideological symbols increased dramatically. China was frequently identified as "Communist China," "Beijing regime," "Chinese Communists," "Red China," "monstrous government," "Deng's regime," "authoritarian chinese government," and "the chinese 
communist regime." The violent incident in Beijing was frequently described as "Beijing crackdown," "military assault," "Beijing massacre," "Beijing killings," "Beijing bloodbath," "bloody crackdown," and "Beijing incident." The percentage of ideological symbols was about the same as the time before Sino-U.S. rapprochement in 1970 (Chang, 1989). Throughout the research period, China's official title (People's Republic of China) and its geographical symbol (Mainland China) were seldom mentioned. At the same time, the use of "Beijing" to refer to China decreased steadily as the movement was developing and the power struggle was unfolding. Despite the fluctuation in the use of all the symbols, the general symbol, "China," was dominant in the entire study period. However, a slight decrease in the use of "China" was visible after the violent ending of the prodemocracy movement.

Two months after the Chinese pro-democracy movement was terminated by military force, the amount of use of some symbols returned to the pre-movement period. The New York Times was in the lead, but the other two newspapers seemed to be slow to follow.

The Washington Post also decreased the percentage of use of ideological symbols from 26\% (June 4, 1989 -- June 20,1989 ) to $8 \%$ (Aug. 6, $1989--$ Aug. 19, 1989). It was still significantly higher than the percentage in the premovement period, which was $0 \%$ 
While the percentage of using one of the general symbols (China) in The New York Times was back to its premovement level, its equivalent in washington Post decreased $0.5 \%$ from its $59.2 \%$ in the last study period. At the same time, the use of "Beijing" as China's identity increased dramatically.

As in the other two newspapers, Los Angeles Times saw a big increase in using ideological symbols to represent China, especially after military troops cleared the demonstrators out of the central square in Beijing. The general symbol, "China," decreased steadily throughout the research periods, though still dominant as far as the percentage goes. Two months after "Beijing Incident," the use of all symbolic representations of China was back to the pre-movement period.

\section{CONCLUSIONS}

Research findings regarding the first research question (How much attention did the three U.S. newspapers give to the 1989 Chinese pro-democracy movement?) indicate dramatic increase in news coverage about the pro-democracy movement in all three newspapers. Of the three newspapers, Los Angeles Times took the lead in both front-page space usage and number of front page stories. This conclusion is strongly supported by two findings. First, under normal circumstances, news coverage about china takes up no more 
than $1 \%$ of the front-page space in the three U.S. newspapers (for details, see findings of the pre-movement period on page 46 and the post-movement period on page 51). During the time of the pro-democracy movement, news coverage of events in China increased to an average of $10 \%$ (for details, see findings in Table III on page 50). Los Angeles Times, in the last study period, used $32.9 \%$ of its front-page space to cover the end of the pro-democracy movement (see the last part of Table II on page 48). The second supportive finding is that news about China seldom gets on the front page of big U.S. newspapers. During the time of Chinese pro-democracy movement, a total of 214 front-page stories were printed in three newspapers together (59 stories in The New York Times, 68 stories in Washington Post, and 87 stories in Los Angeles Times). Besides, each newspaper printed an average of 35 photos on their front pages (see Table IIi on page 50). Findings on the first research question lead to the conclusion that all three U.S. newspapers paid a great deal of attention to events related to the Chinese pro-democracy movement in 1989 .

Findings on the second research question suggest that power struggle on the top level of the Chinese government presented some degree of confusion and ambiguity to the U.S. newspapers. Almost all news reports about the power struggle showed some difficulties in predicting who was actually winning the power struggle. Often times Li Peng 
was seen as losing power and zhao ziyang was viewed as gaining power before martial law was imposed in Beijing on May 20, 1989. The confusion and uncertainty might be related to two factors: 1) Power struggle in the Chinese government was not public. Instead, political struggle on the top level of the chinese government went on behind closed doors and the news media was under tight control of the government; 2) Rumors took up a large percentage of the news reports at that time. Everyone, including professional western journalists inside China and out, had tremendous difficulties sorting out truth from falsehood. As a result, most news reports were based on hearsay or even on pure rumors. All in all, the three newspapers perceived the top three Chinese leaders as losing power, except the party leader Zhao Ziyang, who was seen as gaining power before martial law was imposed in Beijing on May 20, 1989.

Findings on the third research question demonstrate that the image of China changed negatively during the prodemocracy movement, especially after army troops used force to clear Tiananmen Square which was occupied by demonstrators from late April until early June, 1989. The negative change in the image of China is reflected by the use of symbolic representations of china in the three newspapers. The use of ideological symbols increased from $6.4 \%$ to $31.2 \%$ in The New York Times, from $11 \%$ to $25.7 \%$ in Washington Post, and from $2 \%$ to $27.2 \%$ in Los Angeles Times. 
Overall, the increase in the use of ideological symbols is over $15 \%$ in the three newspapers from the first study period to the last. At the same time, the use of nonideological symbols ("China"/"Beijing") decreased from $68.1 \% / 23.2 \%$ to $55.8 \% / 9.8 \%$ in The New York Times, from $66.9 \% /$ $19.9 \%$ to $59.2 \% / 12.8 \%$ in Washington Post, and from $73.3 \% /$ $21.7 \%$ to $58.7 \% / 12.5 \%$ in Los Angeles Times during the entire pro-democracy movement in 1989.

The use of China's official title, the People's Republic of China, did not see much change in all four research periods (see Table VIII on page 57 for details). Two months after June 4,1989 , the use of all symbolic representations of China returned to the level in the pretest period, though the use of ideological symbolc was still a little high with an average of $4.4 \%$ (see Table IX on page 61).

On the basis of research findings, it may be concluded that the image of China, in the perception of the three U.S. newspapers, changed negatively during and right after the Chinese pro-democracy movement in 1989.

\section{LIMITATIONS AND IMPLICATONS}

The present research is limited to three of the leading U.S. newspapers. The findings of this study, therefore, may not be applicable to other printed media or other means of mass media, like TV or radio. Weaver, Porter and Evans 
(1982) conducted longitudinal research (1972-1981) on foreign news coverage on U.S. network television. One of their findings showed significant decline in the volume of news time devoted to stories from Asia. The discussion part of the research provided the following statement:

It is conceivable, of course, that a foreign event of substantial prominence could occur which would temporarily elevate the amount of foreign content offered. However, support for this speculation was not readily apparent (Weaver, Porter, and Evans, 1984).

With more facilities, experience, and research means, future research should expand and include U.S. network television as research data and see if the findings would support the above statement.

The present study yielded findings which support the above speculation in the sense that the amount of foreign news content increased dramatically in the three U.S. newspapers during the time when the Chinese pro-democracy movement took place in China. Future research should attempt to address this aspect in the field of telecommunication.

Mass communication, especially television and radio broadcasting, have a strong impact on the perception of the general public towards any given issue. Perception of the American public about china might have changed in many ways during and after the Chinese pro-democracy movement in 1989. George Skelton stated on the front page of Los Angeles Times that, 
The high regard Americans had for China only three months ago has turned bitterly sour in the wake of the communist regime's bloody suppression of pro-democracy demonstrator, according to The Times Poll. In a dramatic turnaround, three-fourths of the American public now has an unfavorable "overall opinion of China," the poll found. In sharp contrast, three-fourths of Americans held a favorable opinion in March (Skelton, Los Angeles Times, June 18, 1989, Part I, p.1).

According to the findings of the present study, the image of China, as seen in the press, changed negatively during and after the 1989 Chinese pro-democracy movement. Given the fact that news media affect the perception of the public, it is speculated that the perception of the American public about China changed negatively during and right after the Chinese pro-democracy movement in 1989. However, the present study only provides support for this speculation in terms of U.S. newspapers. The effect of television and other means of mass communication on the American public remains an issue for the future research.

Again, the present study only addressed the reaction of three U.S. newspapers towards the chinese pro-democracy movement in 1989. It is likely that other means of mass communication portrayed the pro-democracy movement similarly. Additional research should reuse or modify the research questions in this study to examine and provide support for this speculation. In addition, findings in the future could be used to assess the difference and similarity between printed media and other means of mass communication 
on the issue of any given foreign event of prominence.

It is important to note that this study addressed only questions regarding how the three U.S. newspapers portrayed the Chinese pro-democracy movement in 1989. All other means of U.S. news media and effect of mass media on the American public are beyond the scope of this study. This limition makes it impossible to draw conclusions generalizable to other aspects of mass communication. The findings of this study suggest that high possibilities exist that other means of mass communication would produce similar results if future research is conducted by a similar research method with similar research questions. However, only when future research is conducted in a broader sense could we assertain such speculation. 


\section{REFERENCES}

BOOKS AND JOURNAL ARTICLES

Allen, T. H. (1976). U.S.-China dialogue, 1969-1971. Journal of Communication. Winter, 81-86.

Barelson, B. (1952). Content analysis in communication research. New York: Free Press.

Barelson, B. \& Janowitz, M. (1966). Reader in public opinion and communication, (2nd, ed.). New York: Free Press.

Barrett, B. (1977). Studies on the press. HMSO.

Bennett, W. L. (1980). Public opinion in American politics. New York: Harcourt Brace Jovanovich, Inc.

Bond, F. (1967). An introduction to journalism. New York: The Macmillan Company.

Budd, R. W. (1988). Beyond media: new approaches to mass communication. Transaction Inc., New Brunswick, New Jersey.

Butterfield, F. (1989). Chinese Aide, Visiting U.S., Sees Room for Compromise. The New York Times, May, 23, 1989, A-14.

Carnfield, G. A. (1978). The press and society. Longman, London.

Chaney, D. (1981). Public opinion and social change: The social rhetoric of documentary and the concept of news. In E. Katz \& T. Szecsko (Ed.), Mass media and social change, (pp.115-136). SAGE Publications, Inc., Beverly Hills, California.

Chang, T. K. (1989). The news and U.S.-China policy: symbols in newspapers and documents. Journalism Quarterly, 65, 320-327.

Coffey, M., Frerich, J., and Bishop, R. (1978). China watchers and the Cultural Revolution. Journalism Quarterly, 54, 77-83. 
Cumings, B. (1981). Chinatown: foreign policy and elite realignment. In T. Ferguson \& J. Rogers (Ed.), The Hidden Election, (pp.196-231). New York: Pantheon Books.

Davison, W. P. \& Yu, F. T. (Ed.). (1974). Mass communication research -- major issues and future directions. Praeger Publishers, New York, Washington, London.

Defleur, M. \& Dennis, E. E. (1981). Understanding mass communication. Houghton Mifflin Company, Boston.

Defleur, M.\& Ball-Rokeach, S. (1977). Theories of mass communication. ( $3 r d$, ed.), New York: Longman.

Dennis, E. E. (1989). Reshaping the media. SAGE Publications, Inc.

Donohue, G. A., Tichenor, P. J. \& Olien, C. N. (1972). Gatekeeping: mass media system and information control. In F. G. Kline \& P. J. Tichenor (Ed.), current perspectives in mass communication research, (pp.41-69). Beaverly Hills, Sage.

Driel, B. \& Richardson, J. (1988). Print media coverage of new religious movements: a longitudinal study. Journal of Communication. 38 (3), Summer, 37-62.

Edwin, E. (1972). The press and America: an interpretative history of the mass media. (3rd ed.). Prentice-Hall, Inc., Englewood Cliffs, New Jersey.

Elliot, P. (1982). Press performance as political ritual, Socialogical review monograph, 29, 141-178.

Emery, M. C. \& Smythe, T. C. (1972). Readings in mass communication -- concepts and issues in the mass media. Wm. C. Brown Company Publishers. Dubuque, Iowa.

Fabre, M. (1963). A history of communication. Hawthorn Books, New York.

Fields, E. E. (1984). Preachers, press, and politics: The media career of a conservative social movement, PH.D, University of Oregon.

Gans, H. (1980). Deciding what's news. New York: Vintage.

Gitlin, T. (1980). The whole world is watching. London: University of California Press Ltd. 
Golding, P. (1981). The missing dimensions - News media and the management of social change. In E. Katz \& $T$. Szecsko (Ed.), Mass media and social change. (pp.63-81). SAGE Publications, Inc., Beverly Hills, California.

Grant, P. (1987). The training of journalists in France, Britain and the U.S.. Journalism Quarterly, 64, 582588 .

Hall, E. (1959). The silent language. New York: Doubleday.

Herbert, J. G. (1979). Deciding what's news? Pantheon Books, New York.

Hiebert, R. E., Ungurait, D. F.\& Bohn, T. W. (1982). Mass media. Longman, New York \& London.

Hirsch, P. M. (1981). Institutional functions of elite and mass media. In E. Katz \& T. Szecsko (Ed.), Mass media and social change, (pp.187-200). SAGE Publicaitons, Inc., Beverly Hills, California.

Holsti, O. R. (1969). Content analysis for the social sciences and humanities. Reading, Massachussets: Addison-Wesley.

Horkheimer, M. (1972) . Critical theory. NY: Seabury press.

Howitt, D. (1982). The mass media and social problems. Pergamon Press.

Huang, J. C. (1973). Heroes and villains in Communist china. New York: PICA Press.

Hurtgen, S. (1980). How four U.S. papers covered the Communist Chinese revolt. Journalism Quarterly, 56, 175-178.

Kaplan, A. (1964). The conduct of inquiry. SF: Chandlen.

Kidder, L. H. \& Judd, C. M. (1986). Research methods in social relations. Holt, Rinehart and winston.

Klapper, J. T. (1960). The efforts of mass communication. Glencoe, III: Free press.

Kline, F. G. \& Tichenor, P. J. (Ed.) . (1972) . Current perspectives in mass communication research. SAGE Publications, Inc. 
Knightley, P. (1982). The first casualty. Deutsch, London.

Korobeinikov, V. S. (1981). Mass intercourse and mass information in the process of social development. In E. Katz \& T. Szecsko (Ed.), Mass media and social change, (pp.53-62). SAGE Publications, Inc., Beverly Hills, California.

Krippendorff, K. (1980). Content analysis -- an introduction to its methodology. SAGE Publications, Inc.

Lasswell, H. D. (1949). Languages of politics. South Norwalk, Conn: George W. Stewart.

Lazarsfeld, P. \& Merton, R. (1960). Mass communication, popular taste and organized action. In Wilbur Schramm (Ed.), Mass communication. University of Illinois Press, Urbana.

Lin, C. \& Salwen, M. B. (1987). Three press systems view Sino-U.S. normalization. Journalism Quarterly. 63, 360-365.

Linsky, M. (1986). Impact -- how the press affects federal policymaking. W. W. Norton \& Company. New York. London.

MacFarqubar, R. (1989). Beijing create a no-win situation. The New York Times, May 23, 1989, A-29.

Manoff, R. K., \& Schudson, M. (Ed.). (1986). Reading the news. New York: Pantheon Books.

McCombs, M. E. \& Becker, L. B. (1979). Using mass communication theory. Prentice-Hall, Inc., Englewood Cliffs, New Jersey.

McQuail, D. (1987). Mass communication theory: an introduction (2nd ed.). SAGE Publications Ltd.

Mohr, C. (1989). Army may be trying to avoid crisis. The New York Times, May 23, 1989, A-14.

Nimuno, D. \& Combs, J. (1983). Mediated political reading. NY: Longman.

Noelle-Neumann, E. (1981). Mass media and social change in developed societies. In E. Katz \& T. Szecsko (Ed.), Mass media and social change, (pp.137-165). SAGE Publications, Inc., Beverly Hills, California. 
Oliphant, C. A., (1963), The image of the United States projected by Peking Review, Journalism Quarterly, 40, 416-420.

Peterson, T. (1976). The social responsibility theory. In F. S. Siebert, T. Peterson \& W. Schramm (Ed.), Four theories of the press, (pp.73-105). University of Illinois Press, Chicago.

Phelan, J. (1977) Mediaworld: programming the public. NY: seaury Press.

Righter, R. (1978) . Whose news? Deutch, London.

Romano, C. (1986). The grisly truth about facts. In Manoff \& Schudson (Ed.), Reading the news, (pp.38-52). New York: Pantheon Books.

Rosengren, K. E. (1981). Mass media and social change: some current approaches. In E. Katz \& T. Szecsko (Ed.), Mass media and social change, (pp.274-263). SAGE Publications, Inc., Beverly Hills, California.

Rosenthal, A. M. (1989). The truth of China. The New York Times, May 23, 1989, A-29.

Rubin, R. B., Rubin, A. M. \& Piele, L. J. (1986) . Communication research: strategies and sources. Belmont, CA: Wadsworth.

Schramm, W. (1973). Man, messages and media: a look at human communication. New York: Harper \& Row.

Semmel, A. K. (1977). Foreign news in four U.S. elite dailies: some comparisons. Journalism Quarterly. 53, 732-736.

Siebert, F. S., Peterson, T., \& schramm, W. (1976). Four theories of the press. Chicago: University of Illinois press.

Sigal, L. V. (1986). Sources make the news. In Manoff \& Schudson (Ed.), Reading the news, (pp.14-29). New York: Pantheon Books.

Skelton, G. (1989). Regard for China plummets in U.S.. Los Angeles Times, June 18, 1989, A-1.

Smith, A. (1979). The newspaper: an international history. Thames \& Hudson. 
Steinberg, C. S. (1970). Mass media and communication. Hastings House, Publishers, New York.

Stempel III, G. H. \& Westley, B. H. (Ed.). (1981). Research methods in mass communication. Prentice-Hall, Inc., Englewood Cliffs, New Jersey.

Stempel III, G. H. (1981). Content analysis. In G. H. Stempel III \& B. H. Westley (Ed.), Research methods in mass communication, (pp.119-131). Prentice-Hall, Inc., Englewood Cliffs, New Jersey.

Tan, A. S. (1986). Mass communication theories and research. New York: Macmillan Publishing Company.

Tuchman, G. (1978). Making news: a study of the construction of reality. New York: Free Press.

Tuchman, G. (1981). Myth and the conciousness industry. In E. Katz \& T. Szecsko (Ed.), Mass media and social change, (pp.83-100). SAGE Publications, Inc., Beverly Hills, California.

Utt, S. M. \& Pasternack, S. (1985). Front pages of U.S. daily newspapers. Journalism Quarterly, 61, 879-884.

Walker, M. (1983). Powers of the press. NY: The Pilgrim Press.

Wang, K. \& Starck, K. (1973). Red China's external propaganda during Sino-U.S. rapprochement. Journalism Quarterly, 49, 674-678.

Weaver, J. B., Porter, C. J. \& Evans M. E., (1984), Patterns in foreign news coverage on U.S. network TV: A 10-year analysis, Journalism Quarterly, 61.

Weiss, W. (1968). The effects of the mass media of communication. In G. Lindzey \& E. Aronson (Ed.), Handbook of social psychology, (pp.77-124). Reading, Mass: Addison-Wesley.

White, A. (1970). Truth. Garden City, New York: Anchor \& Doubleday.

Williams, R. (1968) . Communications. Chatto \& Windus, London.

Wright, C. (1975). Mass communication: a sociological perspective, (2nd, ed.). New York: Random House. 
NEWSPAPER ARTICLES USED IN THIS STUDY

From THE NEW YORK TIMES (In Chronological Order)

Kristof, N. D. (1989, April 15). Hu Yaobang, 73, dies in China; led Communist Party in 1980s. P.A-10.

WuDunn, S. (1989, April 16). Hu's death is stirring unrest. p. A-38.

Kristof, N. D. (1989, April 18). Privately, more and more Chinese say it's past time for Deng to go. p.A-1.

Kristof, N. D. (1989, April 19). Thousands chant for democracy within earshot of China's leaders. p.A-1.

WuDunn, S. (1989, April 20). Thousands again protest in Beijing. p.A-8.

Kristof, N. D. (1989, April 22). 100,000 defy a ban of protests in Beijing to demand democracy. p.A-1.

Kristof, N. D. (1989, April 23). Violent protests reported in China -- several hundred are said to riot in a provincial city. p.A-1.

Kristof, N. D. (1989, April 24). Beijing students plan to press democracy drive. p.A-3.

Kristof, N. D. (1989, April 25). China bans pro-student newspaper. p.A-3.

Kristof, N. D. (1989, April 26). Beijing hints at crackdown on students. p.A-3.

Kristof, N. D. (1989, April 28). Troops overwhelmed as rally in capital lasts for 14 hours. p.A-1.

WuDunn, S. (1989, April 29). Students are cool to Beijing's terms for talks. p.A-5.

Kristof, N. D. (1989, May 1). In China, protest proves easier than organization. p.A-1.

WuDunn, S. (1989, May 4). Beijing rejects deadline for talks and students march in defiance. p.A-10.

WuDunn, S. (1989, May 5). Workers joining student in Beijing demonstrations. p.A-8. 
WuDunn, S. (1989, May 6). China newspapers try new openness. p.A-4.

WuDunn, S. (1989, May 9). Voice of America has won the ear of China. p.A-15.

WuDunn, S. (1989, May 10). 1,000 Chinese journalists call for greater freedom of press. p.A-8.

WuDunn, S. (1989, May 11). 5,000 Chinese students hail journalists. p.A-3.

Kristof, N. D. (1989, May 14). China party chief appears to gain in power struggle. p.A-1.

Kristof, N. D. (1989, May 14). China's hero of democracy: Gorbachev. p.A-10.

Keller, B. (1989, May 15). Gorbachev visits Beijing for start of summit talks. P.A-1.

WuDunn, S. (1989, May 15). students in China flood main square -- presence of protesters forces leadership to shift site of Gorbachev's welcome. p.A-8.

Kristof, N. D. (1989, May 16). Gorbachev meets Deng in Beijing; protest goes on. p.A-1.

Keller, B. (1989, May 17). Soviets and China resuming normal ties after 30 years; Beijing pledges 'democracy.' p.A-I.

Kristof, N. D. (1989, May 17) . 300,000 hold rally. p.A-1.

WuDunn, S. (1989, May 18). Resolute student protesters are now the pride of Beijing. p.A-1.

Keller, B. (1989, May 18). Gorbachev praises the students and declares reform is necessary. p.A-1.

Kristof, N. D. (1989, May 18). Crowds in street ask Deng's ouster. $\mathrm{p} \cdot \mathrm{A}-1$.

WuDunn, S. (1989, May 19). Hunger strikers, heart of China protest. p.A-1.

Kristof, N. D. (1989, May 19). Chinese premier issues a warning to the protesters. $\mathrm{p} . \mathrm{A}-1$.

WuDunn, S. (1989, May 20). Sad but defiant, Chinese stand up to troops. p.A-1. 
Kristof, N. D. (1989, May 20). Bid to end 'chaos.' p.A-1. Pear, R. (1989, May 20). U.S. voices regret at events in China. p.A-6.

Hays, C. L. (1989, May 20). China orders end to TV broadcasts. p.A-7.

WuDunn, S. (1989, May 21). Facing the people, the soldiers fall back. p.A-1.

Kristof, N. D. (1989, May 21) . Defy martial law. p.A-1.

Pear, R. (1989, May 21). Diplomats say China is mired in crisis it could have averted. p.A-18.

Butterfield, F. (1989, May 21). In Beijing protests, changes by Deng return to vex him. p.A-20.

Kristof, N. D. (1989, May 21). Armed only with optimism, China's people rise again. Section $4, \mathrm{p} .1$.

WuDunn, S. (1989, May 22). Since martial law, protest crackles with fury at Deng. p.A-1.

Kristof, N. D. (1989, May 22). Beijing throngs again thwart advances by troops amid signs military balks at crackdown. p.A-1.

Butterfield, F. (1989, May 22). Dissident in the U.S. hears of deep cracks in the party. p.A-10.

Kristof, N. D. (1989, May 22). The 8 disparate decision makers: Will they be able to restore calm? p.A-12.

Kristof, N. D. (1989, May 23). Deng to retire in the U.S., and other Chinese rumors. p.A-1.

kristof, N. D. (1989, May 23). A blow to Li Peng. p.A-1.

WuDunn, S. (1989, May 23). Shortages and anarchy begin to cripple Beijing. p.A-12.

Butterfield, F. (1989, May 23). Chinese aide, visiting U.S., sees room for compromise. p.A-14.

Pear, R. (1989, May 23). Radio broadcasts report pro-student demonstrations breaking out all over China. p.A-14.

Rosenthal, A. M. (1989, May 23). The truth of China. p.A-29. 
MacFarquhar, R. (1989, May 23). Beijing creates a no-win situation. p.A-29.

Kristof, N. D. (1989, May 24). Changes at top are hinted as leaders meet in Beijing; some troops began to leave. p.A-1.

WuDunn, S. (1989, May 24). Boldly and subtly, China's press tests limits. p.A-11.

Gerard, J. (1989, May 24). China allows foreign broadcasters to resume news transmission. p.A-11.

Kristof, N. D. (1989, May 25). Power struggle goes on in tense Beijing. p.A-1.

Gerard, J. (1989, May 25). China again cuts off TV mews transmission. p.A-10.

Butterfield, F. (1989, May 25). In China, chaos among the leaders. P.A-11.

Kristof, N. D. (1989, May 26). Tide turns toward Chinese hard-liner. p.A-1.

WuDunn, S. (1989, May 26). Students plan for hurdle: Zhao's fall. p.A-8.

Kristof, N. D. (1989, May 27). Chinese hard-liner tightens grip as attacks on his rival multiply. p.A-1.

Kristof, N. D. (1989, May 28). Chinese students urge end to siege of Beijing square. p.A-l.

Bishop, K. (1989, May 28). China exchange: from gossip to trash bags. p.A-17.

Kristof, N. D. (1989, May 29). Students renew call for change in Beijing's march. p.A-1.

Kristof, N. D. (1989, May 30). Chinese students, in aboutface, will continue occupying square. p.A-1.

WuDunn, S. (1989, May 30). Workers' resistance lags in Beijing. p.A-10.

WuDunn, S. (1989, May 31). In quest for democracy, a minicity is born. p.A-12.

Kristof, N. D. (1989, June 1). Why Deng trembles. p.A-8. 
Kristof, N. D. (1989, June 2). Political sway of the military is subtly spreading in China. p.A-1.

Kristof, N. D. (1989, June 2). Beijing tightens press restriction. p.A-8.

Kristof, N. D. (1989, June 3). Beijing residents block army move near city center. p.A-1.

Kristof, N. D. (1989, June 4). Troops attack and crush Beijing protest; thousands fight back, scores are killed. p.A-1.

WuDunn, S. (1989, June 4). In streets, anguish, fury and tears. p.A-1.

Pear, R. (1989, June 4). President assails shootings in China. p.A-21.

Kristof, N. D. (1989, June 5). Beijing death toll at least 300; army tightens control of city but angry resistance goes on. p.A-1.

WuDunn, S. (1989, June 5). In Beijing, rage and despair over the soldiers' brutality. p.A-1.

Kristof, N. D. (1989, June 5). Ungoverning China. P.A-10.

Goodman, W. (1989, June 5). Many big stories to tell, but the biggest of all is China. p.A-11.

Mcfadden, R. D. (1989, June 5). The West condemns the crackdown. P.A-12.

Bernstein, R. (1989, June 5). Vast Hong Kong crowd protests Beijing's action. p.A-12.

Safire, W. (1989, June 5). Civil war era. p.A-17.

Kristof, N. D. (1989, June 6). Army rift reported in Beijing; shooting of civilians goes on; Bush bars arms sales to China. p.A-1.

Weinraub, B. (1989, June 6). President spurns other sanctions. p.A-1.

Trainor, B. (1989, June 6) . Civil war for army? P.A-16.

Barron, J. (1989, June 6). One man can make a difference:

This one jousted briefly with Goliath. p.A-16.

Wicker, T. (1989, June 6). Darkness in China. P.A-31. 
Kristof, N. D. (1989, June 7). Artillery firing in suburbs adds to tensions in Beijing; mystery on leaders grows. p. $A-1$.

Pear, R. (1989, June 7) . Broadcasts show widespread unrest. p.A-8.

Kristof, N. D. (1989, June 8). Foreboding grasps Beijing; army units crisscross city; foreigners hurry to leave. p. $A-1$.

Bernstein, R. (1989, June 8). Students in Shanghai wage war of buses with officials. p.A-1.

WuDunn, S. (1989, June 8). Civil warfare as a spectator sport. p.A-12.

Kristof, N. D. (1989, June 9). China's premier reappears; army seems to tighten grip; Bush bars normal ties now. p. $A-1$.

WuDunn, S. (1989, June 9). On the surface, Beijing starts to appear normal. p.A-11.

Friedman, T. L. (1989, June 10). A rocky period lies ahead for Washington and Beijing. P.A-5.

Bernstein, R. (1989, June 10). In Shanghai, protesters turn defiant. P.A-7.

WuDunn, S. (1989, June 11). Chinese arrest 400 in Beijing amid fears of a wide purge; roundups on in other cities. p.A-1.

Kristof, N. D. (1989, June 11). Relations with U.S. seem badly hurt by crushing of democracy protests. p.A-16.

Butterfield, F. (1989, June 11). Deng reappears with a chilling lesson about power in China. Section 4, p.1.

Kristof, N. D. (1989, June 12). China seeks arrest of its top dissident -- U.S. embassy refuge. p.A-1.

Bernstein, R. (1989, June 12). At China's ministry of truth, history is quickly rewritten. p.A-1.

Kristof, N. D. (1989, June 12). Democracy movement: over, for the time being. p.A-8.

Friedman, T. L. (1989, June 13). U.S. and Chinese seek to resolve rift on dissident. p.A-1. 
Kristof, N. D. (1989, June 13). China tightens grip with a ban on group calling for democracy. p.A-1.

Kristof, N. D. (1989, June 14). Moderates appear on Beijing $\mathrm{TV}$, easing fears of wholesale purge. p.A-1.

Bernstein, R. (1989, June 15). Far from Beijing's spotlight, a city bears scare of clashes. P.A-1.

Kristof, N. D. (1989, June 16). 3 Chinese workers sentenced to die for protest role. $\mathrm{P} . \mathrm{A}-1$.

Bernstein, R. (1989, June 16). Foreigners once again find the Chinese wary of contact. $\mathrm{p} \cdot \mathrm{A}-1$.

Butterfield, F. (1989, June 16). Did heavens finally fall on Deng? Some see his defeat in China events. p.A-9.

WuDunn, S. (1989, June 17). In the surface calm of Beijing, what's 'normal' isn't quite. p.A-1.

Bernstein, R. (1989, June 17). China's dual view of western ties. P.A-5.

Kristof, N. D. (1989, June 18). China sentences 8 more to death; sharply attacks U.S. 'interference.' p.A-1.

Bernstein, R. (1989, June 18). In Beijing, it's difficult to find facts or truth. p.A-14.

Kristof, N. D. (1989, June 19). Which China is for real? P.A-1.

From WASHINGTON POST (In Chronological Order)

Southerland, D. (1989, April 16). Ousted China leader dies in Beijing at 73 . p.A-29.

Holley, D. (1989, April 18). Students protests in China. p.A-18.

Holley, D. (1989, April 19). Chinese students demonstrate at Communist Party compound. p.A-21.

Southerland, D. (1989, April 20). Chinese students continue rallies for democracy in Beijing. p.A-29.

Southerland, D. (1989, April 21). China hints at reining in protesters. p.A-18. 
Southerland, D. (1989, April 22). 150,000 Chinese march to demand democracy. P.A-1.

Southerland, D. (1989, April 23). Chinese students call for boycott of classes. p.A-25.

Southerland, D. (1989, April 24). Protesters widen aim in China. p.A-1.

Southerland, D. (1989, April 25). Chinese stage boycott at universities. p.A-1.

Southerland, D. (1989, April 26). Beijing warns students to stop protests. P.A-1.

Southerland, D. (1989, April 27). Chinese students defy party threat. p.A-25.

Southerland, D. (1989, April 28). 100,000 in Beijing mount defiant, peaceful march. p.A-1.

Southerland, D. (1989, April 29). Beijing calls off crackdown on student protesters. p.A-1.

Southerland, D. (1989, April 30). China talks called ruse by students. P.A-1.

Southerland, D. (1989, May 1). Students planning new protests. p.A-19.

Southerland, D. (1989, May 2). Beijing's warnings backfire. P.A-10.

Southerland, D. (1989, May 3). Chinese government rejects demands of students protesters. p.A-16.

Southerland, D. (1989, May 4). Thousands march, protesting Beijing's 'false statements.' p.A-25.

Southerland, D. (1989, May 5). Chinese students ending class boycott after latest march. p.A-19.

Southerland, D. (1989, May 5). Journalists cheer students demonstrating in China. p.A-22.

Southerland, D. (1989, May 9). Top Chinese official promises to promote political reforms. p.A-25.

Southerland, D. (1989, May 10). Chinese journalists demand press freedom. p.A-31. 
Dobbs, M. (1989, May 11). Communist protesters: worlds apart. p. A-23.

Southerland, D. (1989, May 13). Beijing students to petition Gorbachev. p.A-25.

Dobbs, M. (1989, May 14). Gorbachev, Deng to meet on rough roads to reform. $\mathrm{p} . \mathrm{A}-1$.

Southerland, D. (1989, May 14). 1,000 students begin hunger strike in Beijing's main square. p.A-26.

Hoagland, J. (1989, May 15). Gorbachev arrives in Beijing. p. A-1.

Southerland, D. (1989, May 15). Sino-Soviet summit may be Deng's last Hurrah. p.A-1.

Dobbs, M. (1989, May 16). For Gorbachev, a historic but backdoor entry. p.A-1.

Southerland, D. (1989, May 16). Protesters upstage summit. p. A-1.

Dobbs, M. (1989, May 17). Gorbachev, in China, calls for democracy. p.A-1.

Southerland, D. (1989, May 17). Protests in Beijing swell to mass movement. $\mathrm{p} . \mathrm{A}-1$.

Southerland, D. (1989, May 18). 1 million Chinese join in demand for democracy. P.A-1.

Dobbs, M. (1989, May 18). Protest turns Beijing into a carnival. P.A-35.

Southerland, D. (1989, May 19). Leaders fail to sway Chinese protesters. p.A-1.

Dobbs, M. (1989, May 19). Fired editor becomes protest hero. p.A-1.

Dobbs, M. (1989, May 19). Gorbachev ends 'watershed' China visit. p.A-35.

Southerland, D. (1989, May 20). Protesters block Chinese troops in Beijing. p.A-l.

Dobbs, M. (1989, May 20). Symbolic heart of China swells with emotion. p.A-1. 
Hoagland, J. (1989, May 20). Deng gambles on army saving him. p.A-1.

Hoagland, J. (1989, May 21). Students teach army a lesson from Mao. p.A-1.

Southerland, D. (1989, May 2I). Chinese government mum on Zhao's fate. p.A-1.

Dobbs, M. (1989, May 21). People's power meets communist army. p.A-32.

Southerland, D. (1989, May 22). Premier's position said to weaken in power struggle. p.A-1.

Hoagland, J. (1989, May 22). Student amity stops convoy in its tracks. p.A-1.

Southerland, D. (1989, May 23). Calls for premier's resignation grow as crackdown on protesters falters. p.A-1.

Hoagland, J. (1989, May 23). Zhao gambles that tide will turn. p.A-1.

Dobbs, M. (1989, May 23). Journalists link press freedom with aims of student protests. p.A-18.

Dobbs, M. (1989, May 24). Beijing students grow confident they will prevail. p.A-1.

Southerland, D. (1989, May 24). Embattled premier appears to be losing power struggle to more moderate forces. p.A-1.

Southerland, D. (1989, May 25). Chinese politburo seen set to oust moderate party chief. $\mathrm{p} . \mathrm{A}-1$.

Hoagland, J. (1989, May 25). Martial law backfires in Beijing. p.A-53.

Southerland, D. (1989, May 26). China's Premier Li emerges; hard-1iners seen ascendant. P.A-1.

Hoagland, J. (1989, May 26). China's continuing turmoil weakens foreign policy role. p.A-1.

Southerland, D. (1989, May 27). Deng intensifies Chinese campaign against enemies. p.A-1.

Mathews, J. (1989, May 27). Beijing intellectuals fear new repression. p.A-1. 
Southerland, D. (1989, May 28). Students call rallies in China. p.A-1.

Southerland, D. (1989, May 29). Chinese students vow to stay in main square. p.A-1.

Mathews, J. (1989, May 29). Wuhan wakes to Minzhu. P.A-1.

Hoagland, J. (1989, May 29). Deng faces quest for successors to shamed Zhao, and himself. p.A-20.

Southerland, D. (1989, May 30). Students build statue in Chinese square. p.A-9.

Southerland, D. (1989, May 31). Chinese in struggle for raw power. $\mathrm{p} \cdot \mathrm{A}-1$.

Mathews, J. (1989, May 31). Goddess of democracy rises. p.A-17.

Mathews, J. (1989, June 2). Chinese army moving closer to protesters. p.A-1.

Southerland, D. (1989, June 3). Chinese citizens block troops from reaching central square. p.A-1.

Mathews, J. (1989, June 3). Chinese students waited quietly in Tiananmen for army action. p.A-12.

Southerland, D. (1989, June 4). Troops roll through Beijing to crush protesters; hundreds feared killed as Chinese fight back. p.A-1.

Mathews, J. (1989, June 4). Students confront tear gas, troops in Chinese capital. P.A-1.

Dewar, H. (1989, June 4). Bush decries Chinese decision to use force. p.A-1.

Southerland, D. (1989, June 5). Citizens defy troops despite massacre of at least 700. p.A-1.

Southerland, D. (1989, June 5). Death in Tiananmen. p.A-1.

Hoagland, J. (1989, June 5). A Beijing casualty: China's reputation. p.A-21.

Burgess, J. (1989, June 5). Protesters march in Hong Kong. P.A -23 .

MCAllister, B. (1989, June 5). Lawmakers ask strong U.S. action. p.A-24. 
Southerland, D. (1989, June 6). Military maneuvers in Beijing raise prospect of civil war. $\mathrm{p} . \mathrm{A}-1$.

Southerland, D. (1989, June 6). Battle tanks seize position on Avenue of Eternal Peace. p.A-1.

Hoffman, D. \& Dewar, H. (1989, June 6). Bush suspends military sales to China. p.A-1.

Oberdorfer, D. (1989, June 6). U.S. Signals opposition to use of force. p.A-16.

Burgess, J. (1989, June 6). Despairing students flee campuses in Beijing. p.A-17.

Mathews, J. (1989, June 7). Shanghai protesters try to avoid clashes. p.A-1.

Southerland, D. (1989, June 7). Residents in Beijing welcome some troops. p.A-1.

Broder, D. S. (1989, June 7). Thatcher halts arms sales to China. p.A-16.

Southerland, D. (1989, June 8). Forces loyal to Deng tighten hold on city. p.A-1.

Oberdorfer, D. \& Hoffman, D. (1989, June 8). U.S. orders dependents to leave China. p.A-1.

Burgess, J. (1989, June 8). Crisis hits home for foreigners. P.A-1.

Mathews, J. (1989, June 8). Workers in shanghai firebomb train that killed protesters blocking rails. p.A-33.

Southerland, D. (1989, June 9). Chinese president gains new power. P.A-1.

Burgess, J. (1989, June 9). Chinese premier praises troops; crackdown on dissident intensifies. p.A-1.

Hoffman, D. \& Devroy, A. (1989, June 9). Bush bids China to recognize 'Aspirations' of protesters. p.A-1.

Ottaway, D. B. (1989, June 9). China sanctions opposed despite 'step backward.' p.A-19.

Lubman, S. (1989, June 9). Beijing life reverts to normal, almost. p.A-30. 
Shales, T. (1989, June 9). Keeping open the China gate. section $C, p .1$.

Burgess, J. \& Southerland, D. (1989, June 10). China's Deng reappears as fear of arrests grows. p.A-1.

Richburg, K. B. (1989, June 10). Asian nations wary about China policies. p.A-14.

Devroy, A. (1989, June 10). White House condemns China 'murder.' p.A-14.

Southerland, D. (1989, June 10). Deng's appearance has strong impact on Beijing. p.A-15.

Burgess, J. (1989, June 11). China says hundreds of protesters held. p.A-1.

Southerland, D. (1989, June 11). Turmoil transforms Chinese life. P.A-1.

Burgess, J. (1989, June 12). China seeks to arrest dissidents in Embassy. p.A-1.

Burgess, J. (1989, June 12). Images vilify protesters. p.A-1.

Burgess, J. (1989, June 13). China steps up criticism of United States. p.A-1.

Oberdorfer, D. (1989, June 13). U.S. criticizes Deng but seeks to avoid showdown on dissident. p.A-20.

Randolph, E. (1989, June 13). Clampdown on coverage seen in China. p.A-20.

Kirkpatrick, J. (1989, June 13). The Beijing spring. p.A-27.

Burgess, J. (1989, June 14). China calls for arrest of 21 students. p.A-1.

Sun, I. H. (1989, June 14). Stability, economic progress may elude China's emerging hard-line government. p.A-27.

Southerland, D. (1989, June 15). Role of military is said to strengthen. $\mathrm{p} . \mathrm{A}-1$.

Burgess, J. (1989, June 15). State-run TV focusing on student arrest. P.A-1. 
Burgess, J. (1989, June 16). Climate of fear grips China. P. A-1

Burgess, J. (1989, June 16). Shanghai court issues 1st known death sentences since massacre. p.A-30.

Southerland, D. (1989, June 17). Defiance of the privileged. p.A-1.

Burgess, J. (1989, June 17). Chinese government spokesman indicates party chief is out. p.A-16.

Weisskopf, M. (1989, June 18). 8 sentenced to death by court in Beijing. p.A-1.

Oberdorfer, D. (1989, June 18). Shifts seen in China's global ties. p.A-1.

Burgess, J. (1989, June 19). Chinese government issues new restrictions on foreign travel. p.A-24.

Lubman, S. (1989, June 19). Study groups employed as key propaganda tool. p.A-24.

Weisskopf, M. (1989, June 20). Political crisis in Beijing seen easing. p.A-1.

From LOS ANGELES TIMES (In Chronological order)

Holley, D. (1989, April 18). Chinese marchers honor reformer. Part I, p.5.

Holley, D. (1989, April 19). China police break up prodemocracy protest. Part $I, p .1$.

Holley, D. (1989, April 21). Beijing student rally protest police tactics. Part I, p.16.

Holley, D. (1989, April 22). Thousands join Beijing march for democracy. Part I, p.1.

Holley, D. (1989, April, 23). 130 police hurt as rioting hits 2 China cities. Part $1, \mathrm{p} .1$.

Holley, D. (1989, April 24). Beijing students boycott classes. Part I, p.I.

Holley, D. (1989, April, 25). Beijing students stage rallies, seek to spread protests. Part I, p.11. 
Holley, D. (1989, April 26). China charges 'conspiracy' in student protests. Part I, p.I.

Holley, D. (1989, April 27). Students defy chinese decree against protests. Part I, p.1.

Holley, D. (1989, April 28). Beijing students win concession. Part I, p.1.

Holley, D. (1989, April 29). Beijing students weigh talks offer. Part I, p.3.

Holley, D. (1989, April 30). Beijing talks denounced by protesters. Part I, p.1.

Holley, D. (1989, May 1). China seeks to mollify its students. Part I, p.1.

Holley, D. (1989, May 2). China students seek official status, call talks a sham. Part I, p. 6 .

Holley, D. (1989, May 3). China rejects activists' ultimatum. Part I, p. 6 .

Holley, D. (1989, May 4). Students push through police lines in Beijing march. Part I, p.13.

Holley, D. (1989, May 5). Chinese savor a pro-democracy celebration. Part I, p.8.

Holley, D. (1989, May 11). Thousands of Chinese on bicycles protest censorship. Part I, p.8.

Parks, M. \& Holley, D. (1989, May 14). Sino-Soviet talks to open new era. Part I, p.1.

Holley, D. (1989, May 14). Beijing protesters start a hunger strike. Part I, p.20.

Parks, M. \& Holley, D. (1989, May 15). Gorbachev in Beijing for historic talks. Part I, p.1.

Holley, D. (1989, May 15). China moves ceremony from square. Part I, p.1.

Parks, M. (1989, May 15). Deng and Gorbachev: great reformers battling socialist crises. Part I, p.10.

Parks, M. \& Holley, D. (1989, May 16). Leaders declare China-Soviet ties are normalized. Part I, p.1. 
Holley, D. (1989, May 17). China vows more democracy in bid to quell protests. Part I, p.1.

Holley, D. (1989, May 18). Students want Deng, premier to resign; marches in 24 cities. Part $I$, p.I.

Holley, D. (1989, May 19). Protest crisis splits China's leaders. Part $I, p .1$.

Holley, D. (1989, May 20). Party chief in struggle for power. Part I, p.I.

Mann, J. (1989, May 20). Deng's ties to military reinforce political power. Part I, p.1.

Rosenberg, H. (1989, May 20). High drama in CNN countdown to blackout. Part I, p.15.

Holley, D. (1989, May 21). Chinese defying martial law, seek premier's ouster. Sunday Final, p.1.

Holley, D. (1989, May 22). Protesters retain control of square. Part I, p.1.

Mann, J. (1989, May 22). China upheaval likely to force major changes. Part I, p.I.

Mann, J. (1989, May 23). China's army uneasy about a crackdown. Part I, p.1.

Holley, D. (1989, May 23). Avoid force on protesters, letter advises. Part I, p.1.

Holley, D. (1989, May 24). Growing protests in China threaten to topple premier. Part I, p.1.

Gerstenzang, J. (1989, May 24). Crackdown would hurt ties, Bush warns Chinese. Part I, p.I.

Sharbutt, J. (1989, May 24). China lets U.S. networks resume live TV coverage. Part I, p.11.

Holley, D. \& Schoenberger, K. (1989, May 25). Chinese leaders fighting an epic battle for control. Part I, p.1.

Bremner, D. (1989, May 25). China's power struggle like a family spat; elders try to repair split. Part I, p.13.

Schoenberger, K. (1989, May 25). Protesters want reformer Zhao as their champion. Part I, p.14. 
Sharbutt, J. (1989, May 25). China again bans live U.S. TV reports. Part I, p.14.

Holley, D. \& Mann, J. $(1989,26)$. Deng, Li seen winning China power struggle. Part I, p.1.

Schoenberger, K. (1989, May 26). Fresh recruits for student army arrive by rail to join Beijing's war of nerves. Part I, p. 20 .

Schoenberger, K. \& Mann, J. (1989, May 27). Sweeping purge expected as China's leader gather. Part I, p.1.

Holley, D. (1989, May 27). Premier Li Peng: loyal party man, champion of China's old guard. Part I, p.18.

Schoenberger, K. \& Holley, D. (1989, May 28). Students defy regime with march in Beijing. Part $I, p .1$.

Gargan, E. A. (1989, May 28). Great crossroads in the square. Part $V, p .1$.

Schoenberger, K. (1989, May 29). Dispirited protesters in China vow to carry on. Part I, p.1.

Mann, J. \& Holley, D. (1989, May 30). Key reformer may be out of job in Beijing. Part I, p.1.

Schoenberger, K. (1989, May 30). Storm of protests fails to ruffle Beijing's expatriates. Part I, p.12.

Mann, J. (1989, May 31). Beijing move to oust zhao appears stalled. Part I, p.12.

Schoenberger, K. (1989, May 31). China labor activists emulate solidarity. Part I, p.12.

Williams, D. (1989, May 31). No 'Goddess' shown on China TV. Part I, p.13.

Mann, J. \& Holley, D. (1989, June 2). Beijing threatens curbs on foreign reporting. Part $I, p . I$.

Holley, D. (1989, June 2). Beijing students' bravery sparked epic drama. Part I, p.39.

Holley, D. \& Mann, J. (1989, June 3). Tear gas fired at Beijing protesters. Part $I, p .1$.

Williams, D. (1989, June 3). China activist of '79 wishes current crop well. Part I, p. 20. 
Mann, J. \& Holley, D. (1989, June 4). Troops fire on Beijing crowds; at least 100 dead, 400 hurt; Square is recaptured. Sunday Final, p.1.

Gerstenzang, J. \& Holley, D. (1989, June 4). Bush deplores troop assault on China crowd. Sunday Final, p.l.

Mann, J. \& Holley, D. (1989, June 5). Firing convoys roam Beijing. Part I, p.1.

Jehl, D. (1989, June 5). Congress steps up pressure for China sanctions. Part I, p.1.

Mann, J. (1989, June 5). Leadership of party is steering country on perilous course. Part I, p.14.

Mathews, L. (1989, June 5). Army's attack on civilians called 'incredible blunder.' Part I, p.15.

Williams, D. (1989, June 5). Despair, anger over killings engulf Beijing residents. Part $I$, p.16.

Pollack, J. D. (1989, June 5). Deng's actions discredit legitimacy of his rule. Part II, p.5.

Holley, D. \& Williams, D. (1989, June 6). China teeters on edge of civil war as rival forces mobilize. Part I, p.1.

Gerstenzang, J. (1989, June 6). Bush halts arms sales over China repression. Part $I, p .1$.

Williams, D. (1989, June 6). China campuses become shrines for the fallen. Part I, p.1.

Mann, J. (1989, June 6). Rival armies may clash in Beijing soon, diplomats say. Part I, p.8.

Holley, D. \& Williams, D. (1989, June 7). Military clashes, new party chief reported in China. Part I, p.1.

Williams, D. (1989, June 7). Rumors rule Beijing as city disintegrates. Part $I$, p.1.

Broder, J. M. (1989, June 7). China military divided by regional, ethnic rivalries. Part $I$, p.I.

Fritz, S. \& Kempster, N. (1989, June 7). Senate unanimously urges additional steps against China regime. Part I, p.11. 
Jehl, D. (1989, June 8). Rigid regime paved way for national chaos. Part I, p.I.

Mann, J. (1989, June 8). Chinese leaders reportedly fled to military base. Part I, p.10.

Broder, J. M. (1989, June 8). Beijing troop moves seen as mostly 'Jockeying.' Part I, p.10.

Williams, D. \& Holley, D. (1989, June 9). China hard-liners appear in control. Part I, p.I.

Holley, D. \& Williams, D. (1989, June 10). Economic reforms to continue, Deng vows. Part I, p.1.

Schoenberger, K. (1989, June 10). Shanghai students defy regime, hold protest. Part I, p.1.

Goldman, J. (1989, June 10). Thousands rally to cries of 'shame.' Part I, p.12.

Williams, D. (1989, June 10). Dissent on campus withers away. Part I, p.13.

Holley, D. \& Williams, D. (1989, June 12). Arrest of dissident in U.S. embassy is sought by China. Part I, p.1.

Mann, J. (1989, June 12). Brazen Beijing killings: two theories arise. Part I, p.1.

Holley, D. (1989, June 13). Beijing imposing nationwide ban on protest groups. Part I, p.8.

Holley, D. (1989, June 14). China hunts for student leaders. Part I, p.1.

Williams, D. (1989, June 14). Signs of fervor nearly erased from Beijing. Part I, p.1.

Holley, D. (1989, June 15). China orders 2 U.S. reporters out of country. Part $I, p .1$.

Schoenberger, K. \& Holley, D. (1989, June 16) . 3 sentenced to die for burning Shanghai train. Part I, p. 1.

Williams, D. (1989, June 16). Now, Beijing is targeted in criticism on human rights. Part $I, p .8$.

Kempster, N. \& Williams, D. (1989, June 17). Bush act to ease Sino-U.S. tension. Part I, p.1. 
Schoenberger, K. (1989, June 17). Chengdu quiet after echoing Beijing clash. Part I, p.I.

Skelton, G. (1989, June 18). Regard for China plummets in U.S.. Part I, p.I.

Kempster, N. \& Williams, D. (1989, June 18). U.S. acts to restore trade ties with China. Part $I$, p. 1 .

Williams, D. (1989, June 19). China imposes news curbs on travel abroad. Part $I$, p. 1 .

Schoenberger, K. (1989, June 20). China cuts back forces in Beijing. Part $I$, p.12. 


\section{APPENDIX}

\section{CODING SHEET A: MOVEMENT COVERAGE}

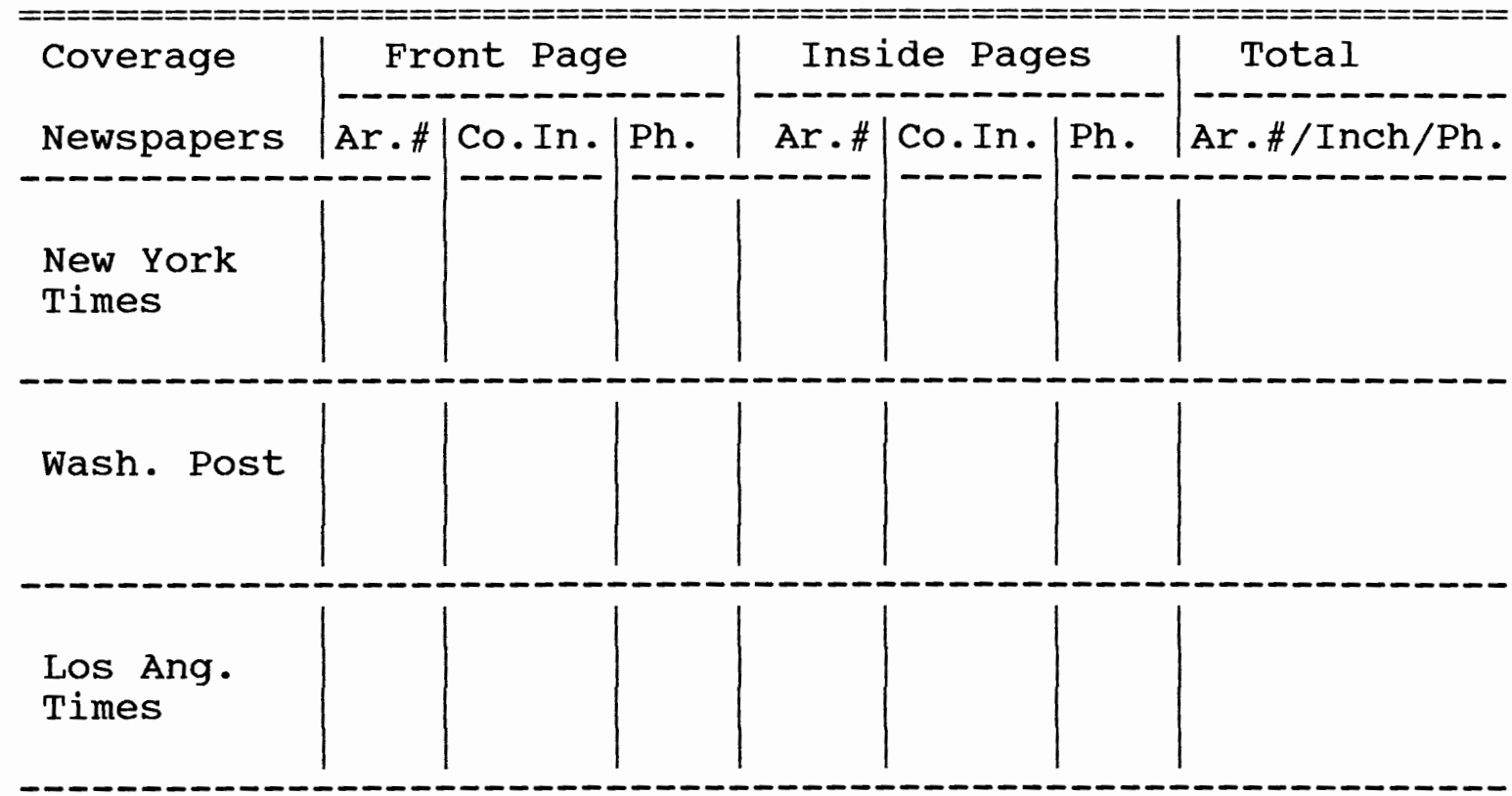

NOTES : 
CODING SHEET B: POWER STRUGGLE

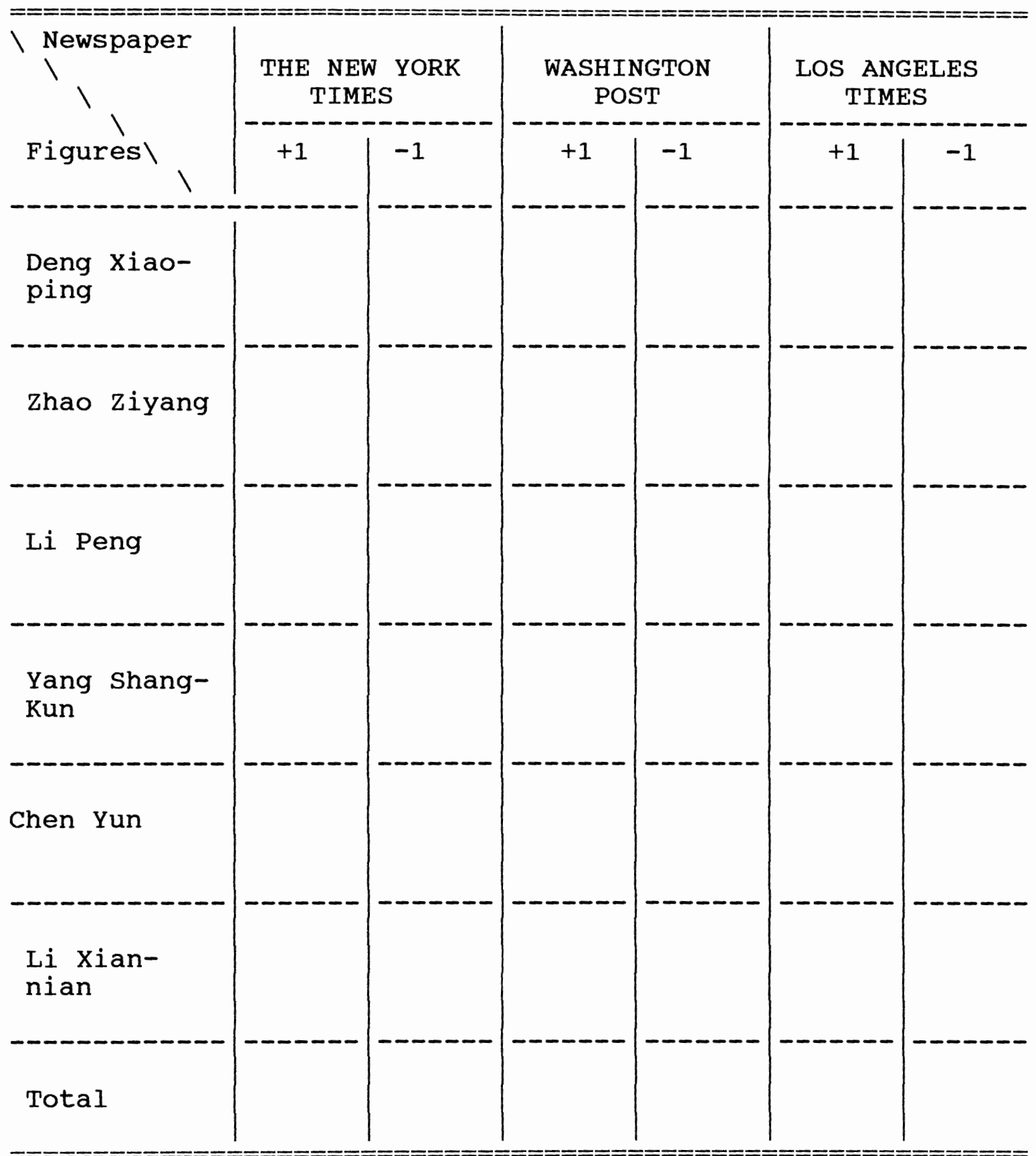


CODING SHEET C: CHANGE IN IMAGE OF CHINA

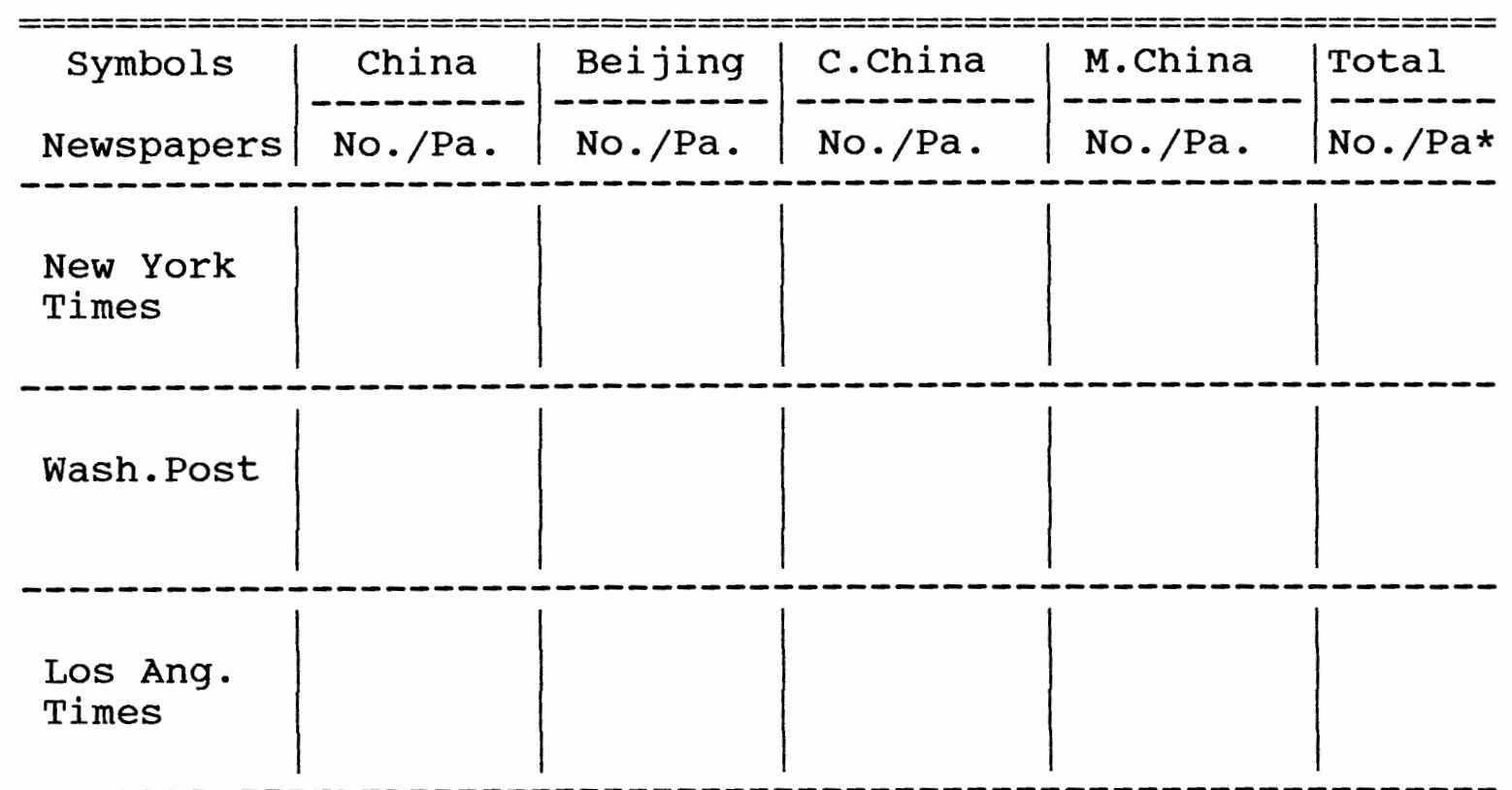

NOTES :

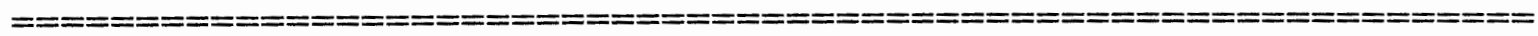
*indicates the number of paragraphs from which symbols are drawn. 